Review

\title{
Clinical Biological and Genetic Heterogeneity of the Inborn Errors of Pulmonary Surfactant Metabolism
}

Mohammed Tredano', Jacques de Blic², Matthias Griese $^{3}$, Jean-Christophe Fournet ${ }^{2}$, Jacques Elion ${ }^{4}$ and Michel Bahuau'

\author{
${ }^{1}$ Service de Biochimie et Biologie Moléculaire, Hôpital d'En- \\ fants Armand-Trousseau, Paris, France \\ ${ }^{2}$ Service de Pneumologie et Allergologie Pédiatriques et Ser- \\ vice d'Anatomie et Cytologie Pathologiques, Hôpital des En- \\ fants-Malades, Paris, France \\ ${ }^{3}$ Kinderklinik und Kinderpoliklinik, Dr. von Haunerschen Kinder- \\ spital, Ludwig-Maximilians Universität, München , Germany \\ ${ }^{4}$ Service de Biochimie Génétique et INSERM U458, Hôpital \\ Robert-Debré, Paris, France
}

Pulmonary surfactant is a multimolecular complex located at the air-water interface within the alveolus to which a range of physical (surface-active properties) and immune functions has been assigned. This complex consists of a surface-active lipid layer (consisting mainly of phospholipids), and of an aqueous subphase. From discrete surfactant sub-fractions one can isolate strongly hydrophobic surfactant proteins $B$ (SP-B) and C (SP-C) as well as collectins SP-A and SP-D, which were shown to have specific structural, metabolic, or immune properties. Inborn or acquired abnormalities of the surfactant, qualitative or quantitative in nature, account for a number of human diseases. Beside hyaline membrane disease of the preterm neonate, a cluster of hereditary or acquired lung diseases has been characterized by periodic acid-Schiff-positive material filling the alveoli. From this heterogeneous nosologic group, at least two discrete entities presently emerge. The first is the SP-B deficiency, in which an essentially proteinaceous material is stored within the alveoli, and which represents an autosomal recessive Mendelian entity linked to the SFTPB gene (MIM 1786640). The disease usually generally entails neonatal respiratory distress with rapid fatal outcome, although partial or transient deficiencies have also been observed. The second is alveolar proteinosis, characterized by the storage of a mixed protein and lipid material, which constitutes a relatively heterogeneous clinical and biological syndrome, especially with regard to age at onset (from the neonate through to adulthood) as well as the severity of associated signs. Murine models, with a targeted mutation of the gene encoding granulocyte macrophage colonystimulating factor (GM-CSF) (Csfgm) or the $\beta$ subunit of its receptor (//3rb1) support the hypothesis of an abnormality of surfactant turnover in which the alveolar macrophage is a key player. Apart from SP-B deficiency, in which a near-consensus diagnostic chart can be designed, the ascertainment of other abnormalities of surfactant metabolism is not straightforward. The disent- anglement of this disease cluster is however essential to propose specific therapeutic procedures: repeated broncho-alveolar lavages, GM-CSF replacement, bone marrow grafting or lung transplantation.

Key words: Surfactant, pulmonary; Pulmonary alveolar proteinosis; SP-B protein deficiency; Hyaline membrane disease; Respiratory distress.

Abbreviations: $\mathrm{BAL}$, bronchoalveolar lavage (fluid); CAP, congenital (pulmonary) alveolar proteinosis; DPPC, dipalmitoylphosphatidylcholine; GM-CSF, granulocyte-macrophage colony-stimulating factor; HMD, hyaline membrane disease; LDH, lactate dehydrogenase; $\mathrm{MBL}$, mannose-binding lectin; PAP, pulmonary alveolar proteinosis; PAS, periodic acid-Schiff; proSPC, SP-C precursor protein; SP, surfactant protein; TA, tracheal aspirate.

\section{Introduction}

Problems related to air breathing occur at many levels, first physical, because air breathing entails the control of forces that tend to collapse the alveoli, maximally in end-expiration, without compromising the efficiency of gas exchange. These problems are also infective and depurant in nature, because the approximately $17 \mathrm{~kg}$ of air breathed daily are liable to contain a large diversity of chemicals, allergens, and pathogens which may cause toxic, inflammatory end infectious problems. The evolution of surfactant systems and of the proteins as specific and integral components shows how, despite the large diversity of present-day pulmonary structures, a single biological mechanism was selected very early during evolution for adaptation to the fundamental problems related to air breathing (1). Indeed, the immunohistochemical analysis of surfactant from lungfish (Neoceratodus forsteri, a species separated from man by approximately 400 million years), based on the utilization of antibodies specifically raised against human surfactant proteins $A$ (SP-A) and C (SP-B), elicits a labelling pattern similar to human surfactant. Any alteration of this interface system, the cause of which may be acquired and transient, or inborn, will cause fundamental, possibly life-threatening, problems.

Components, Structure and Functions of Surfactant: a Lipid and Protein Complex

The main source for the study of surfactant and its components is broncho-alveolar lavage fluid. The sur- 
factant affects the alveolar space, although its surfaceactive properties may extend to the tracheo-bronchial tree. The large body of analyzed material originates from the alveoli, and its raw composition does not mirror the actual heterogeneity of the different physiologic phases. Such heterogeneity is elicited after the fractionation of discrete subfractions using thin-layer chromatography or sucrose gradient. The surface active properties, aimed at lowering the air-liquid interface pressure such as surface tension, come mainly from the phospholipids. These phospholipids are arranged as a layer separated from the apex of the cells by a thin liquid film.

This is no static organization, since the lipid layer undergoes condensation and spreading at each respiratory cycle. It has been estimated that surfactant lowers the surface tension at the pulmonary air-water interface approximately 70 -fold. The absence, or malfunction, of this lipid layer will lead to alveolar collapse, or atelectasis, during expiration (2). Specific proteins (SP-A, SP-B, SP-C, and SP-D) play an important part in the homeostasis of this component, at the levels of both structural organization and functional durability. Lung is not only exposed to atmosphere gases, but also to physical, toxic, infectious, and allergenic insults. This calls for as many specific functions assigned to such proteins.

Lipids make up about $90 \%$ of the molar content of pulmonary surfactant. They are mostly phospholipids containing, in a decreasing order of magnitude, phosphatidylcholine, phosphatidylglycerol, phosphatidylethanolamine, phosphatidylinositol, phosphatidylserine, and sphingomyelins. Among phosphatidylcholines, the dipalmitoylated compound is the most abundant (dipalmitoylphosphatidylcholine: DPPC), accounting for approximately $50 \%$ of these compounds. Finally, cholesterol makes up approximately $8 \%$ of the weight of lipids $(15 \% \mathrm{~mol})$, and there are only traces of triglycerides or non-esterified fatty acids (3) (Table 1).

Proteins make approximately $10 \%$ of the molar content of surfactant. Four of them take up most of the functions devoted to specific surfactant proteins. These are two water-soluble proteins, SP-A and SP-D, and two hydrophobic proteins, SP-B and SP-C (3) (Table 2). SP-A and SP-D are collectins. This means that they contain a collagen-like domain devoted to oligomerization (N-terminal end), and a lectin-like domain allowing for the opsonization of xenobiotics and pathogens (C-terminal end). This sub-family also includes mannose-binding protein (MBL2: mannosebinding lectin) (10) (Figures 1, 2). SP-A is essential, in conjunction with SP-B and ionized calcium, for the scaffolding of tubular myelin, a transitional structure between intracellular and alveolar surfactant. In addition, SP-A regulates the insertion of phospholipids into the lipid layer at the air-liquid interface, modulates the secretion and re-uptake of phospholipids by type II

Tab. 1 Phospholipid content (\%) of pulmonary surfactant. ${ }^{1}$

\begin{tabular}{llcl}
\hline Phospholipids & Term-born neonates & Preterm neonates & SP-B deficient neonates \\
\hline Phosphatidylcholine & 80 & 70 & 75 \\
DPPC (\% of PC) & 70 & 60 & 55 \\
Phosphatidylglycerol & 10 & 0 & 2 \\
Phosphatidylethanolamine & 3 & 5 & 7 \\
Phosphatidylinositol & 5 & 10 & 4 \\
Phosphatidylserine & 2 & 2 & 2 \\
Sphingomyelin & 2 & 15 & 8 \\
\hline
\end{tabular}

${ }^{1}$ The pulmonary surfactant components are indicated for each phospholipid and for each pathophysiological condition as percentages of total phospholipids (for DPPC, percent- age in relation to phosphatidylcholines) (4). DPPC: dipalmitoylphosphatidylcholine; PC: phosphatidylcholine

Tab. 2 Surfactant proteins. ${ }^{1}$

\begin{tabular}{lllll}
\hline Protein & SP-A & SP-D & SP-B & SP-C \\
\hline Type & Water-soluble & Water-soluble & Hydrophobic & Hydrophobic \\
MW of the monomer & $26-38 \mathrm{kDa}$ & $43 \mathrm{kDa}$ & $8.7 \mathrm{kDa}$ & $4.2 \mathrm{kDa}$ \\
Quaternary structure & Octodecamer (trimer hexamer) & Dodecamer (trimer tetramer) & Dimer & Monomer \\
Receptors (MW) & Calreticulin $(\sim 60 \mathrm{kDa})$ & gp-340 $(340 \mathrm{kDa})$ & & \\
& C1qRp (126 kDa) & & & (3) \\
SP-A receptor $(210 \mathrm{kDa})$ & & $(3,8,9)$ & (3) \\
References & $(3,5-8)$ & $(300 \mathrm{kDa})$ & & \\
\hline
\end{tabular}

${ }^{1}$ for the corresponding genes, see Table 3. MW: molecular weight. 
alveolar cells in vitro, activates alveolar macrophages (generation of free radicals), and opsonizes endotoxins and some bacterial capsules (C1q-like function), and aggregates pathogens (Hæmophilus influenzæ type A). SP-A, together with SP-D, is an important element of the non-specific immunity of the pulmonary mucosa (11). SP-D, beside its role in the non-specific activation of macrophages, interferes with phospholipid metabolism. It binds phosphatidylinositol via calcium (3). Some studies have elicited the antiallergenic action of
SP-A and SP-D. Indeed, SP-A and SP-D have the capacity to inhibit the release of histamine by basophils following induction by an allergen (e.g., the fungal glycoprotein of Aspergillus fumigatus) (12). In addition, these proteins inhibit lymphocytic proliferation and histamine release in asthmatic children (13). SP-A and SP-D act as opsonins by means of membrane-bound receptors (8). The best characterized receptor of SP-A is a 210-kDa protein found at the surface of macrophages and type II alveolar cells (14). Additional receptors have

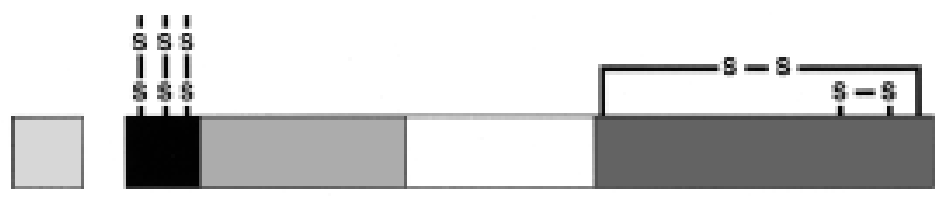

SP-A
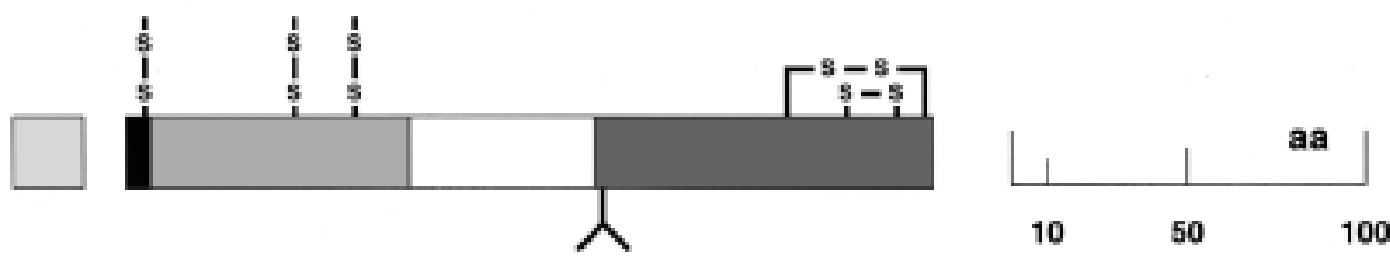

SP-D

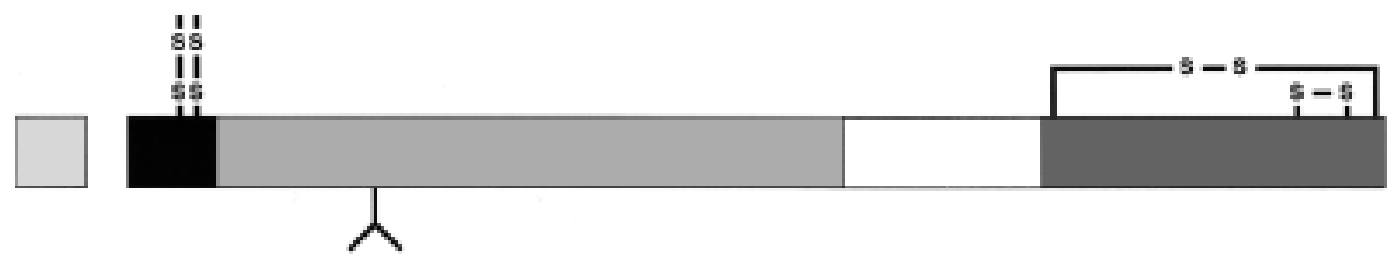

Fig. 1 Primary structure of SP-A and SP-D proteins. Structural homology with the MBL protein is indicated from left to right as follows: light grey, signal peptide; black, cysteine-rich domain; medium grey, collagen-like domain; white, coiled- coil domain; dark grey, type-C lectin domain. Disulfide bonds are indicated for each protein in the lectin type-C domain, the cysteine residues being represented by potential (open) disulfide bonds and the glycosylation sites by fork-like structures.

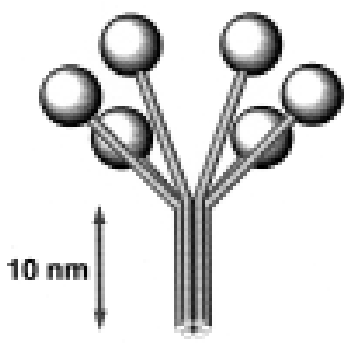

SP-A

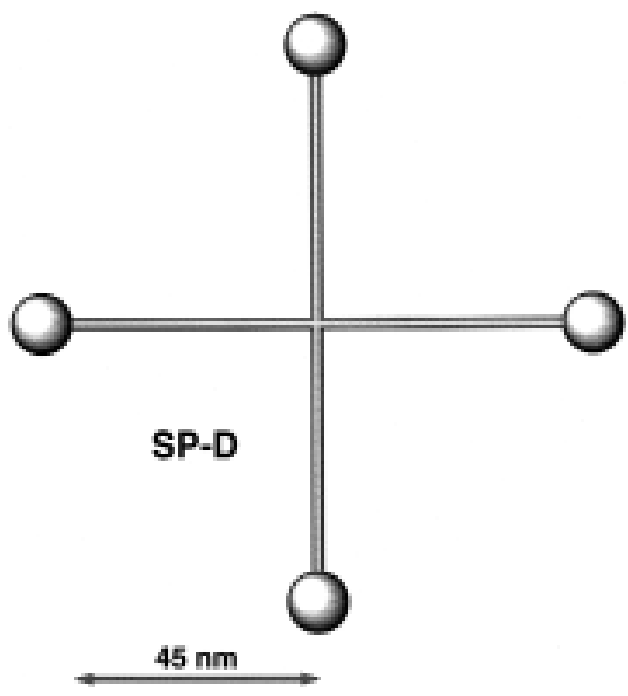

(six for SP-A and four for SP-D), the globular extremity corresponding to the lectin domain (C-terminus).
Fig. 2 Quaternary structures of proteins SP-A and SP-D. These proteins are made from the assembly of homodimers 
been identified on the surface of other cells, especially neutrophils (Table 2). Several studies showed the binding of SP-D to alveolar macrophages. A 340-kDa receptor (gp-340) was recently isolated from broncho-alveolar lavage fluid (9). Whereas it is generally believed that the collagen-like domain of the two collectins SP-A and MBL contains the receptor binding site, it is on the intermediate domain of protein SP-D that the gp-340 binding site was identified (9). Beside the water-soluble proteins, two hydrophobic proteins are intertwined with phospholipids in the air-water interface. These proteins are SP-B and SP-C. SP-B is composed of 79 amino acids and has an apparent molecular weight of 8.7 kDa. Proteolytic cleavage generates the mature protein, with a functional arrangement as a homodimer. SP-C is composed of 35 amino acids and has a molecular weight of $4.2 \mathrm{kDa}$. This protein is strongly hydrophobic, due to a long valine-rich tail and to palmitoylation on two cysteine residues (Figures 3, 4). Overall, SP-B and SP-C's main functions are to catalyze the insertion of phospholipids at the lung air-water interface, to provide the molecular scaffolding of the phospholipid layer, and to stabilize tubular myelin (SP$B$ together with SP-A).

\section{Metabolism}

\section{Synthesis}

The synthesis of surfactant phospholipids and proteins takes place in the microsomal fraction of the type II alveolar cells. Surfactant components are synthesized within the endoplasmic reticulum and translocated to the Golgi apparatus before they are stored as lamellar inclusions (intracellular pool). Once excreted by exocytosis, the lamellar bodies unpack in the subphase to generate tubular myelin (extracellular or alveolar pool), highly ordered transitional structure and precursor of the lipid layer at the air-water interface $(3,21)$ (Figure 5).

\section{Recycling}

Surfactant is continuously excreted and recycled. Indeed, the type II alveolar cells re-uptake surfactant to
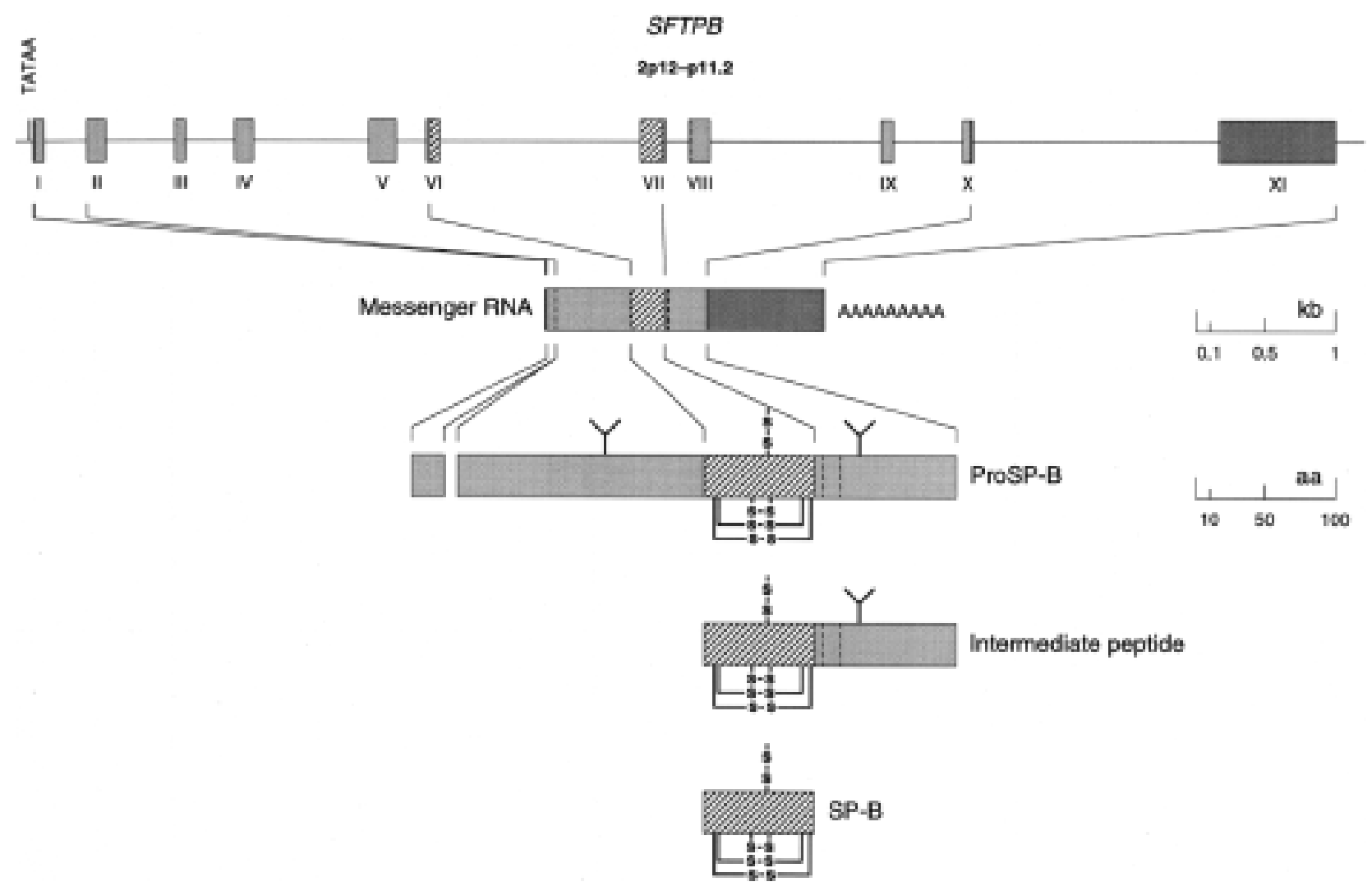

Fig. 3 Gene encoding the SP-B protein (SFTPB) and propeptide processing. The SFTPB gene is localized on the short arm of chromosome 2, in position 2p12-p11.2 (15). It is a relatively small gene spanning $9.5 \mathrm{~kb}$ and composed of 11 exons, only the first ten being coding. The nucleotide sequence corresponding to the mature peptide spans exons 6 and 7 (16). The use of an alternative splice site in the beginning of exon 8 generates a 12-nucleotide shorter messenger. The possible relationship between this messenger and human disease are still speculative. The 381 amino acid (aa)-long precursor (proSP-B), having a molecular weight (MW) of $40 \mathrm{kDa}$, generated by the co-translational cleavage of a 23-residue signal, is again subjected to a two-step proteolytic processing yielding the 79-aa, 8.7-kDa, mature peptide. The first step consists in the cleavage of the $\mathrm{N}$-terminal domain, yielding a 26-kDa intermediate peptide, and the second ends with the cleavage of the C-terminal domain and yielding of the mature peptide (17). The latter step is restricted to the type II alveolar cells. The proteins involved in the catalysis and post-translational processing of the proSPB precursor have not been identified to date. 

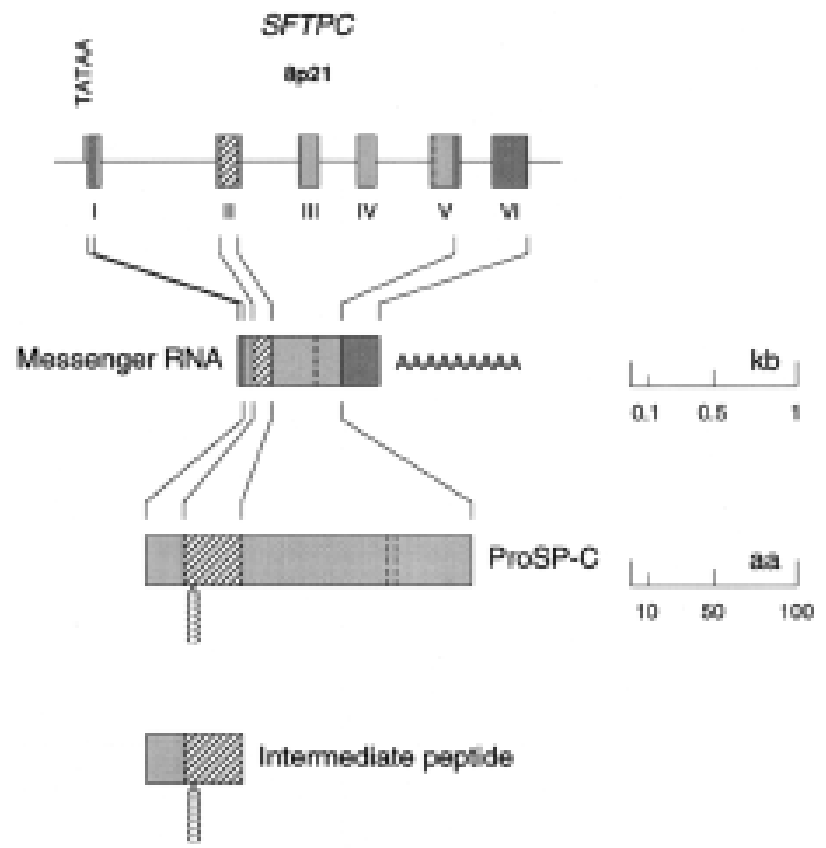

SP-C

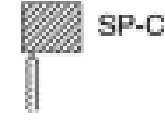

Fig. 4 Gene encoding the SP-C protein (SFTPC) and propeptide processing. The SFTPC gene is localized on the short arm of chromosome 8 , in position 8p21 (18). It is a relatively small gene spanning $3.5 \mathrm{~kb}$ and composed of 6 exons, only the first five being coding (19). The nucleotide sequence corresponding to the mature peptide is restricted to exon 2. The presence of an alternative splice site in the beginning of exon 5 entails two distinct messenger species differing by the insertion or deletion of 18 nucleotides. The possibility of the translation of the long (insertional) species has not been substantiated to this day. The SFTPC gene expression is restricted to the type II alveolar cells. The precursor (proSP-C), having a MW of $22 \mathrm{kDa}$, is again subjected to a two-step proteolytic processing yielding the $65-\mathrm{aa}, 3.5-\mathrm{kDa}$, mature peptide. The first step consists in the cleavage of the C-terminal domain, yielding a $6-\mathrm{kDa}$ intermediate peptide, and the second ends with the cleavage of the $\mathrm{N}$-terminal domain and yielding of the mature peptide. Two cysteine residues present in the mature peptide are subjected to post-translational palmitoylation, which confers an extremely hydrophobic character to the protein (20).

recycle it via lamellar bodies (Figure 5). The control of this process is poorly understood. An important fraction of surfactant is recycled through type II alveolar cells. Alveolar macrophages also have their share in this process, although quantitatively for a lesser part, by phagocytosis. Finally, a minute quantity of pulmonary surfactant seems to be cleared by the airway. It is of note that granulocyte-macrophage colony-stimulating factor (GM-CSF) and its downstream signaling pathway are of importance in this process. Indeed, this cytokine plays an outstanding role in macrophage activation and surfactant recycling, as shown by murine models with a targeted mutation of the gene encoding
GM-CSF (Csfgm/- mice) (22) or the subunit of its receptor (//3rb 1/- mice) (23) (see below).

\section{Genes}

As we have seen for SP-B and SP-C (Figures 3, 4), most of the genes encoding surfactant-specific proteins, or proteins involved in surfactant homeostasis, have been localized and their intron-exon organization is known (Table 3). These genes provide many candidates for monogenic or polygenic factors determining the diversity of primary or secondary disorders of pulmonary surfactant metabolism. Indeed, mutations that lead to inactivation of one of the genes involved in surfactant homeostasis, especially those encoding structural proteins, might, by abating or completely depleting the source of normal protein, cause respiratory distress in a new-born, an infant, a child or an adult. Such mutations could account for the observed recurrence in siblings, especially when they show a recessive pattern of inheritance. On the other hand, slight variation in coding or non-coding regions of these genes might confer a certain risk related to lung disease, which might be primary (without any obvious cause) or secondary to environmental insults. The emerging molecular pathology of these genes in man, or the corresponding murine models detailed below, have in part corroborated this hypothesis (also, see Table 4). Indeed, to investigate the involvement of different candidate genes in the mouse, or to establish models for the human disease, several murine homologues of human surfactant genes were knocked out using homologous recombination. This concerns the genes encoding the water-soluble proteins, SP-A (Sftpa) and SP-D (Sftpd), the gene encoding hydrophobic SP-B (Sftpb), as well as the genes encoding GM-CSF (Csfgm) or the $\beta$ subunit of its receptor (I/3rb1).

\section{Disease Conditions}

\section{$H M D$}

A number of respiratory diseases linked to an abnormality of pulmonary surfactant have been described, with a special mention of hyaline membrane disease of the preterm neonate (HMD) (32). HMD is a common cause for respiratory distress in the newborn and is related to an immaturity of the production and secretion of pulmonary surfactant. Incidence is estimated at $1 \%$ of births in the United States and is inversely proportional to the gestational age and birth weight (33). The absence of an efficient surfactant accounts for alveolar collapse, the generation of hyaline membranes and interstitial edema. Typically, the newborn child is managed in a neonated intensive care unit, specific supportive care resting on oxygen, sometimes early administration of corticoids and assisted ventilation, and finally the endotracheal instillation of replacement 


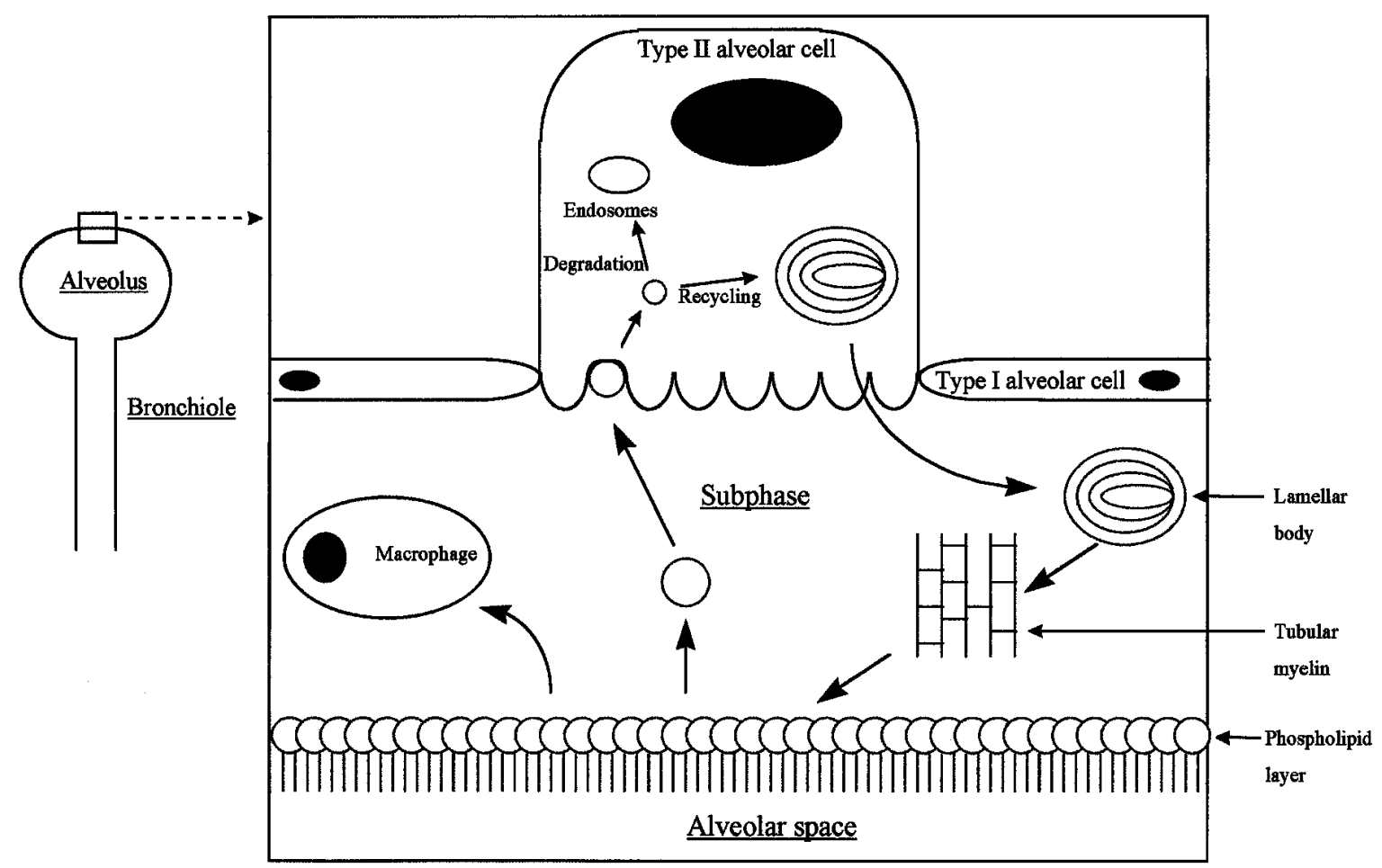

Fig. 5 Surfactant synthesis and turnover. The pulmonary surfactant (phospholipids and proteins) is synthesized by the type II alveolar cell and stored as lamellar bodies. Once excreted, lamellar bodies give birth to tubular myelin, a highly ordinated transitional lamellar structure precursor to the monolayer. Surfactant is recycled or degraded by the type II alveolar cell $(90 \%)$ and the alveolar macrophage (10\%).

Tab. 3 Genes whose products are involved in surfactant homeostasis.

\begin{tabular}{lllll}
\hline Protein & Gene & Localization & MIM1 & Structure \\
\hline SP-A & SFTPA1 & $10 \mathrm{q} 22.2-\mathrm{q} 23.1$ & 178630 & 4 exons \\
& SFTPA2 & $10 \mathrm{q} 22-\mathrm{q} 23$ & 178642 & 4 exons \\
SP-B & SFTPB & $2 \mathrm{p} 12-\mathrm{p} 11.2$ & 178640 & 11 exons \\
SP-C & SFTPC & $8 \mathrm{p} 21$ & 178620 & 6 exons \\
SP-D & SFTPD & $10 \mathrm{q} 23.3$ & 178635 & 7 exons \\
GM-CSF & CSF2 & $5 \mathrm{q} 31.1$ & 138960 & 4 exons \\
GM-CSF receptor, $\alpha$ subunit & CSF2RA & Xp22.32/Yp11.3 & 306250 & 13 exons \\
& & (pseudo-autosomal region) & & \\
GM-CSF receptor, $\beta c$ subunit & CSF2RB & $22 q 12.2-q 13.1$ & 138981 & Introns-exons organization unknown
\end{tabular}

${ }^{1} \mathrm{MIM}$ : Mendelian Inheritance in Man entry number [see Online Mendelian Inheritance in Man, $\mathrm{OMIM}^{\mathrm{TM}}$. McKusick-Nathans Institute for Genetic Medicine, Johns Hopkins University (Balti-

surfactants, either artificial or natural $(34,35)$. It is essential to prevent the development of HMD by balancing the indications for Caesarean sections, especially basing the judgement on the qualitative or quantitative analysis of the surfactant phospholipid material present in amniotic fluid, which mirrors the fetal pulmonary maturation, and by the injection of corticoids to pregnant women $48 \mathrm{~h}$ before birth, especially when the term is below 34 gestational weeks (33). Apart from the two established risk factors of prematurity and low birth weight, the male sex and the pathological condition of the mother (diabetes mellitus), factors such as another case of HMD in siblings, as well as the Caucasian background, relate to possible maternal and/or fetal genetic factors. Indeed, for an identical birth term, more, MD) and National Center for Biotechnology Information, National Library of Medicine (Bethesda, MD), 2000. World Wide Web URL: http://www.ncbi.nIm.nih.gov/omim/].

two newborn babies will have distinct risks for HMD. This fact is especially illustrated in dizygotic twin pairs, which are by definition non-identical in terms of genetic factors and are submitted to a unique environment. These dizygotic twin pairs, in contrast to monozygotic twins, are as discordant with regard to HMD as siblings adjusted for other risk factors would be, and this discordance is likely to be due to genetic factors (36). This not to mention term (a rare occurrence) or near-term-born babies who, despite the absence of established environmental risk factors, develop HMD. Confirming these speculations, Floros and co-workers observed linkage disequilibrium in infants with neonatal respiratory distress syndrome as compared to a control population using the compound in- 
Tab. 4 Murine models. ${ }^{1}$

\begin{tabular}{|c|c|c|c|c|c|c|}
\hline $\begin{array}{l}\text { Gene knock-out } \\
\text { (human } \\
\text { homologue) }\end{array}$ & mRNA & $\begin{array}{l}\text { Surfactant } \\
\text { proteins }\end{array}$ & Phospholipids & Tubular myelin & $\begin{array}{l}\text { Respiratory } \\
\text { phenotype }\end{array}$ & References \\
\hline $\begin{array}{l}\text { Sftpa } \\
\text { (SFTPA) }\end{array}$ & $\begin{array}{l}\text { SFTPA: Absent } \\
\text { SFTPB, SFTPC, } \\
\text { SFTPD: N }\end{array}$ & $\begin{array}{l}\text { SP-B, SP-C, } \\
\text { SP-D: N }\end{array}$ & $\begin{array}{l}\text { Saturated } \\
\text { phosphatidyl- } \\
\text { cholines: } \uparrow\end{array}$ & Absent & $\mathrm{N}$ & $(24,25)$ \\
\hline $\begin{array}{l}\text { Sftpb } \\
\text { (SFTPB) }\end{array}$ & $\begin{array}{l}\text { SFTPB: Absent } \\
\text { SFTPA, SFTPC: N }\end{array}$ & $\begin{array}{l}\text { SP-C: } \downarrow \downarrow \downarrow \\
\text { Aberrant/ } \\
\text { immature } \\
\text { SP-C species }\end{array}$ & ND & Absent & $\begin{array}{l}\text { Death due } \\
\text { to neonatal } \\
\text { respiratory } \\
\text { distress }\end{array}$ & $(26)$ \\
\hline $\begin{array}{l}\text { Sftpd } \\
\text { (SFTPD) }\end{array}$ & $\begin{array}{l}\text { SFTPD: Absent } \\
\text { SFTPA, SFTPB, } \\
\text { SFTPC: N }\end{array}$ & SP-A, SP-B: $\uparrow$ & $\uparrow$ & $\begin{array}{l}\text { ND } \\
\text { (giant lamellar } \\
\text { bodies) }\end{array}$ & $\mathrm{N}$ & $(27)$ \\
\hline $\begin{array}{l}\text { Sftpd } \\
\text { (SFTPD) }\end{array}$ & $\begin{array}{l}\text { SP-D: Absent } \\
\text { SFTPB, SFTPC: N } \\
\text { SFTPA: } \downarrow \text { (modest) }\end{array}$ & $\begin{array}{l}\text { SP-B, SP-C: N } \\
\text { SP-A: } \downarrow \\
\text { (modest) }\end{array}$ & $\begin{array}{l}\text { Saturated } \\
\text { phosphatidyl- } \\
\text { cholines: } \uparrow\end{array}$ & $\downarrow$ & $\mathrm{N}$ & $(28)$ \\
\hline $\begin{array}{l}\text { Csfgm } \\
\text { (CSF2) }\end{array}$ & $\begin{array}{l}\text { SFTPA, SFTPB, } \\
\text { SFTPC: N }\end{array}$ & SP-A, SP-B: $\uparrow$ & $\uparrow$ & $\uparrow$ & PAP & $(22,29,30)$ \\
\hline $\begin{array}{l}\text { II3rbl } \\
\text { (CSF2RB) }\end{array}$ & ND & ND & ND & ND & PAP & $(23,31)$ \\
\hline
\end{tabular}

${ }^{1}$ Mice homozygous for the mutation obtained through homologous recombination. The two Sftpd knock-out models were treated separately. N: Normal; ND: Not determined; PAP: Pul- monary alveolar proteinosis; $\uparrow$ : Increase; $\downarrow$ : Decrease; $\downarrow \downarrow \downarrow$ : Large decrease. sertion-deletion and $(C A)_{n}$ motif repeat polymorphism of SFTPB intron 4 (37). These populations were matched for gender, ethnic background and mean gestational age. Since the variation lies in an intron, it may be that slight changes in the expression of the gene, and not deleterious mutations, confer susceptibility to neonatal respiratory distress syndrome, especially when established risk factors are present. Genetic variation within the genes encoding the SP-A protein (SFTPA1 and SFTPA2 genes) also seems to correlate with the risk for HMD since coding polymorphisms of these genes show statistically significant differences in allele sharing between cases and controls. Of interest is that the odds ratios could differ significantly for a given genotype between the African-American and White Caucasian samples, suggesting that these polymorphisms were likely indirect disease markers rather than causal genetic changes (38). In this study, a significant synergistic positive association was found between an SFTPA2 allele and the SFTPB intron 4 compound polymorphism, suggesting the existence of an interaction between the different polygenic risk factors. More recently, specific genotypes at this locus (SFTPA1 $6 A^{2} / 6 A^{2}$ and $6 A^{3} / 6 A^{3}$ genotypes) were shown to significantly associate with high or low risk for HMD, respectively, based on a case-control study performed in a genetically homogeneous population sample from Finland (39). Correlation with the SFTPB genotype could not be tested because this population showed little polymorphism at this locus. Recently, it was suggested that the SFTPB T1580C (I131T) coding polymorphism was an upstream determinant for certain SFTPA $1 / 2$ alleles causing genetic susceptibility to RDS $\left(6 A^{2}, 1 A^{0}\right)$ or protection against it $\left(6 A^{3}, 1 A^{2}\right)$.
More specifically, allele assortment at the SFTPA1/2 locus was significantly different in RDS as compared with controls only in a subgroup of subjects homozygotes for a threonine in position 131 of the SP-B protein. This important paper sheds new light on the causality of a common SP-B polymorphism in RDS, and shows interaction with the SFTPA 1/2 locus (87).

Interestingly, the SP-A protein in the mouse is encoded by a single gene and murine models with null mutations at this locus were established. The Sftpa ${ }^{-/}$ model is normally viable $(24,25)$ and lung function as well as development are seemingly normal, despite the observed scarcity of tubular myelin. Non-specific abnormalities could be observed, such as delayed clearance of certain bacteria from distal airway: Pseudomonas aeruginosa and Streptococus group B, which demonstrate the subtleness of the phenotype. Obviously, these mice do not replicate the human disease HMD, or any other lung disease known in man. This could be expected because no SFTPA 1/2 deleterious mutations were observed in man, and since these animal models are established as models for monogenic, not polygenic, disease. Whatever the case, these knock-out animals provide a suitable tool for analyzing the biological significance of the SP-A protein in vivo.

\section{Non-HMD abnormalities of surfactant synthesis or turnover}

A number of cases with respiratory distress not included within the nosology of HMD are characterized by a qualitative or quantitative abnormality of surfactant. Among those which are inborn or so reputed, one 


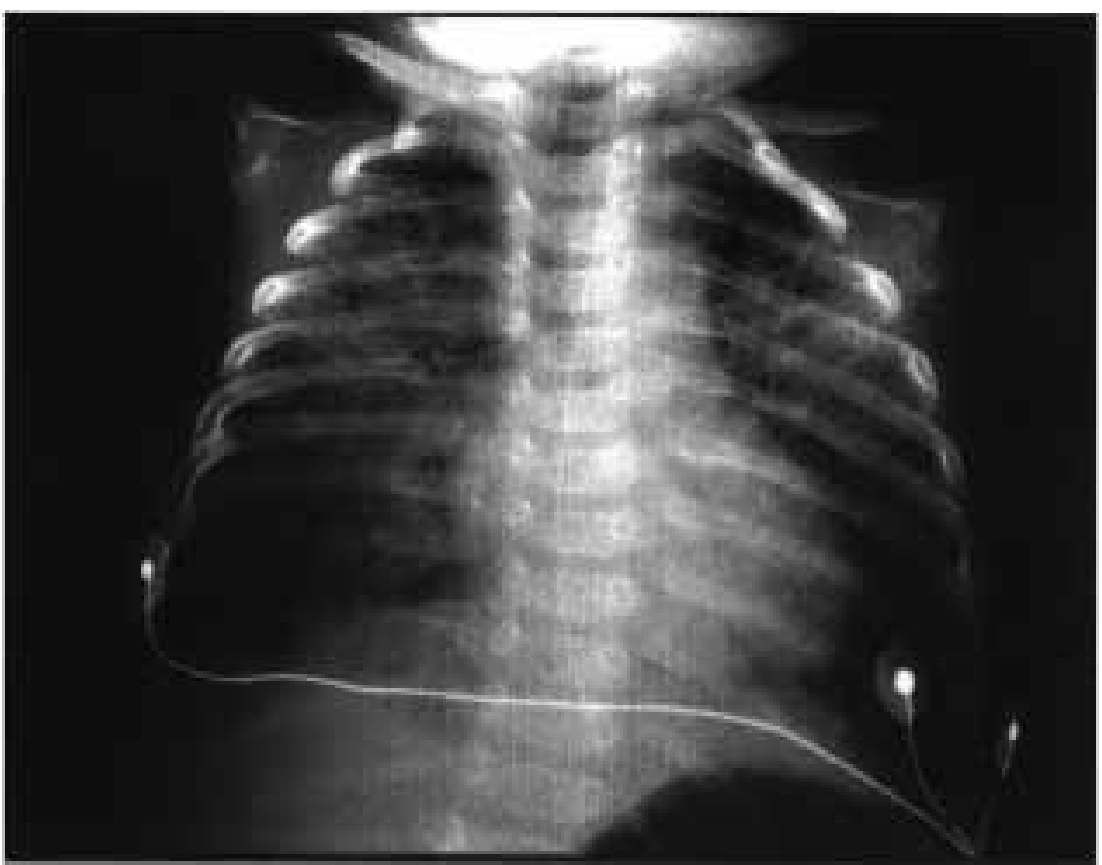

Fig. 6 Chest $x$-ray. This procedure carried out in a 5 monthold infant suffering from severe alveolar proteinosis shows

nodular peri-hilar opacities in the context of diffuse interstitial infiltrates.

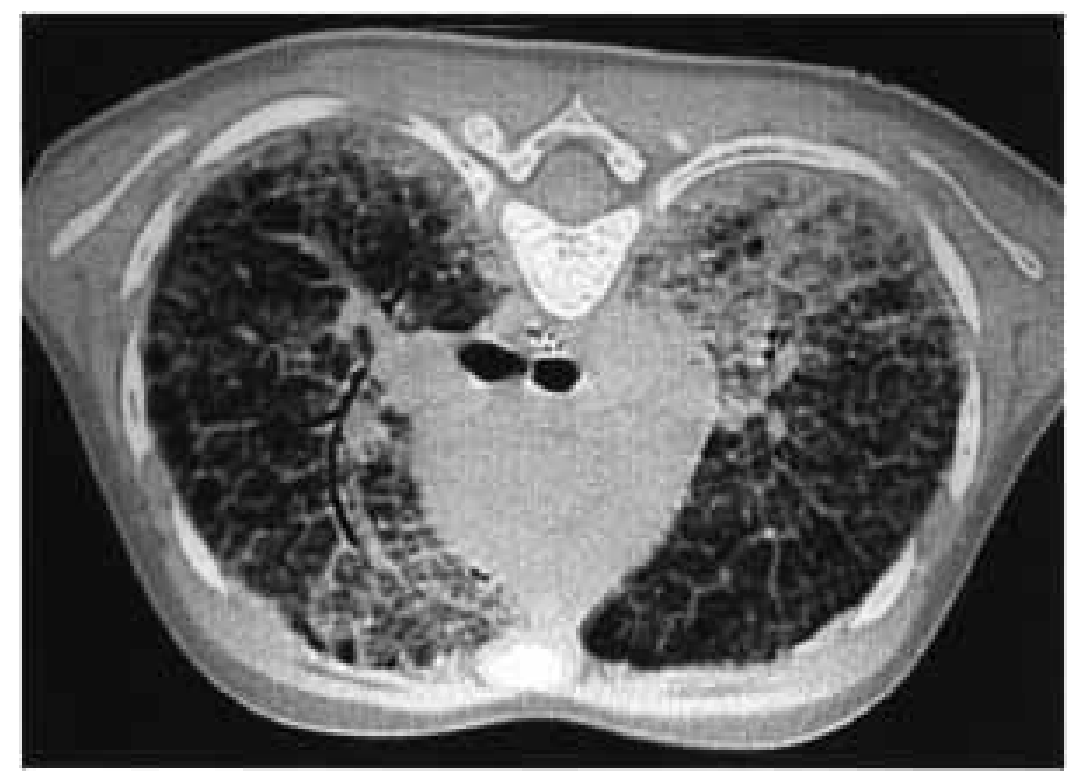

Fig. 7 Chest computed tomography. This procedure, carried out in a 4 year-old child suffering from alveolar proteinosis shows interstitial infiltrates and intra-alveolar filling.

can distinguish alveolar proteinosis, a heterogeneous group from which a certain number of entities seem to emerge. These disorders are being biochemically and pathologically characterized, and their molecular bases elucidated.

\section{Alveolar proteinosis}

Pulmonary alveolar proteinosis (PAP) is a rare respiratory disease, initially reported by Rosen and coworkers some forty years ago (40). This condition is generally idiopathic, although it has been described as being associated to malignant hemopathies (leukemias, lymphomas), or to lysinuric protein intolerance, during or following respiratory infections (nocardiosis, histoplasmosis, pneumocystosis, cytomegaloviral infections), and following exposure to inert particles such as silica. The chest $x$-ray, performed for respiratory distress, which is most often unexplained, shows alveolar opacities, as well as reactional interstitial infiltrates (honeycombing). The pathological examination of lung elicits periodic acid-Schiff 


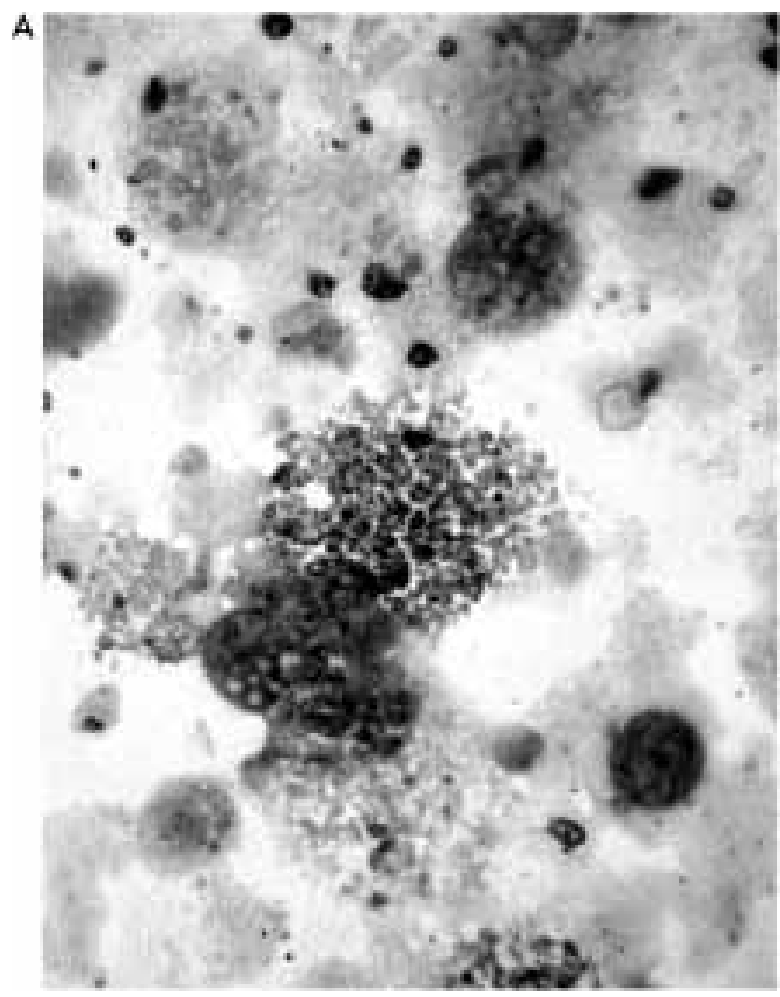

Fig. 8 Analysis of broncho-alveolar lavage fluid after PAS staining (A) shows abundant lumpy proteinaceous material (PAS, $\times 200$ ) among the cells, whereas the standard staining at

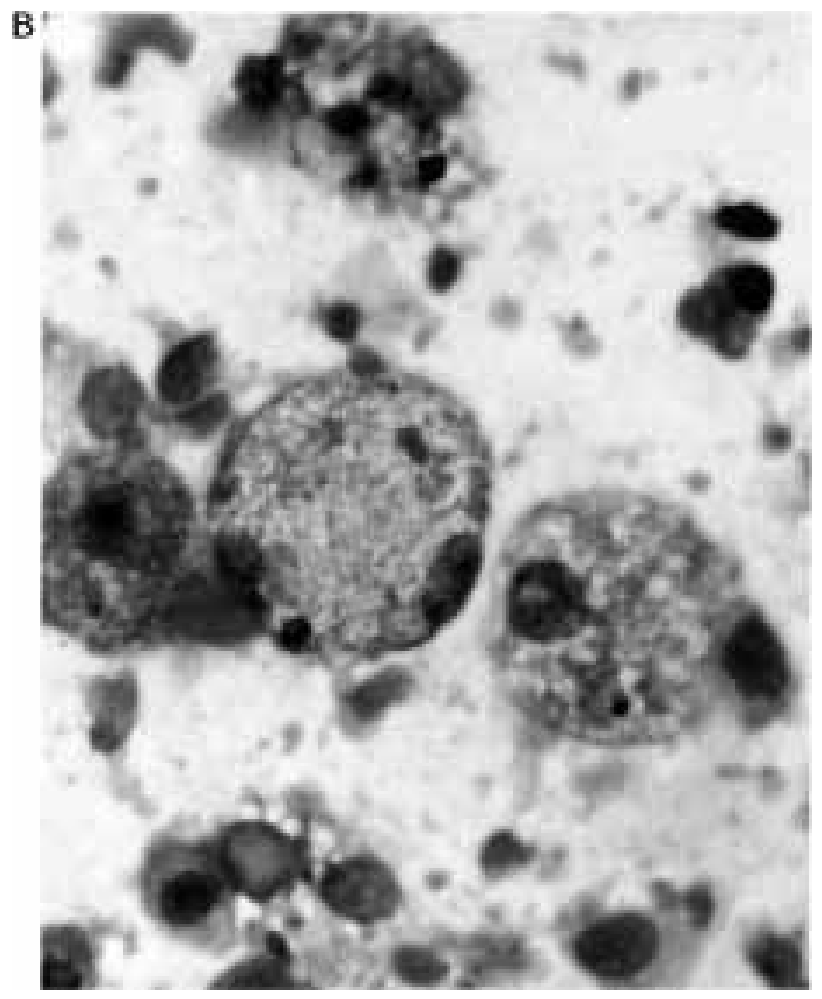

higher magnification (B) shows enlarged macrophages laden with lipid microvacuoles (foamy macrophages; MGG, x 400).

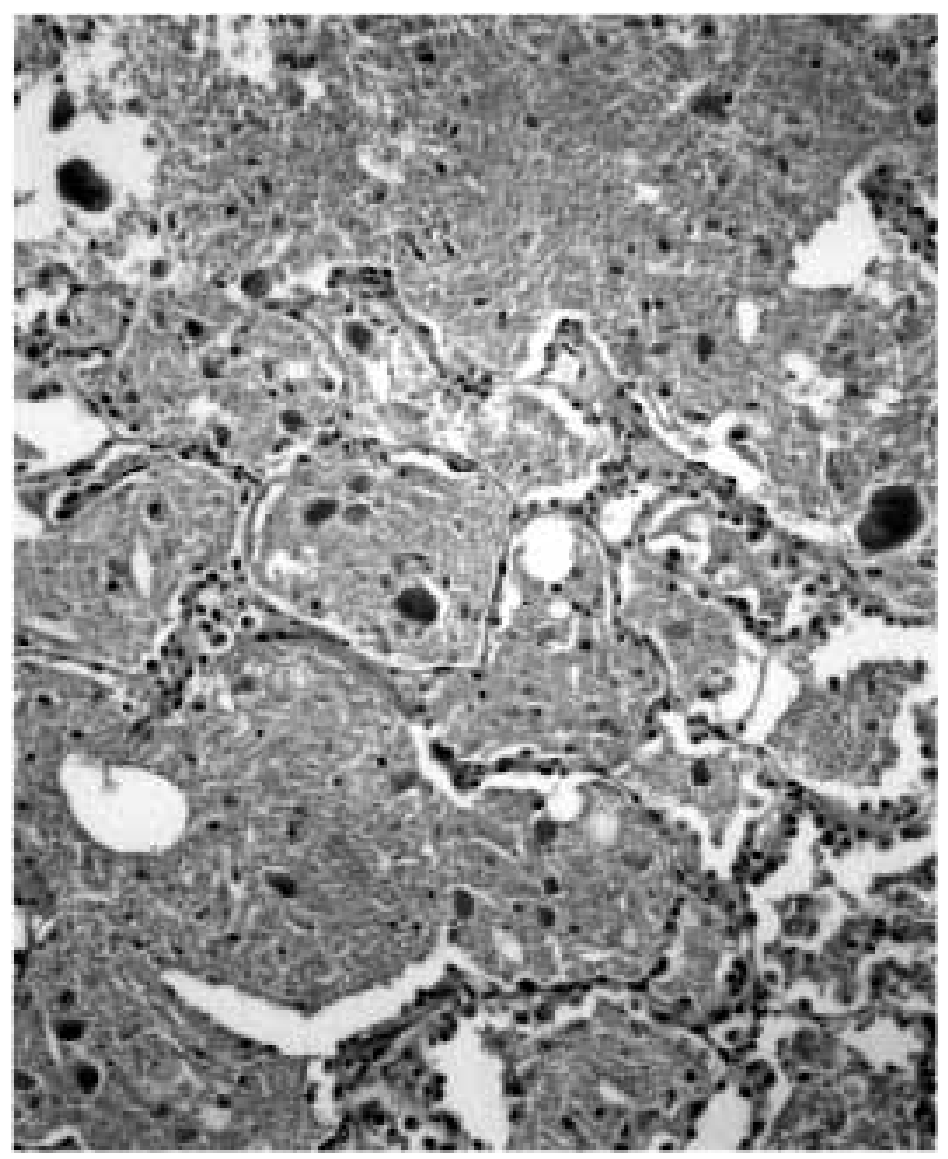

Fig. 9 Histological analysis of pulmonary biopsy sample following PAS staining highlights intra-alveolar filling with abundant, lumpy, lipoproteinaceous, material containing small cholesterol crystals, small chromaffin concretions and foamy macrophages (PAS, $x$ 100). 
(PAS)-positive, protein and lipid, material filling the alveoli (41). PAP is diagnosed prevalently in the adult but pediatric or neonatal forms are also seen $(42,43)$. The pathology of these different forms is regarded as being approximately identical.

PAP in the child and adult. Alveolar proteinosis can be diagnosed at any age, from neonate (42) through to maturity ( 72 years) (43), the age at the diagnosis being most often between 20 and 50 (44). In the child and adult, the revealing signs are, in more than half of the cases, dyspnea and cough with progressive onset, sometimes with cyanosis, finger clubbing, asthenia, and weight loss. The PAP in children is polymorphic. All intermediate forms are possible, from early neonatal forms (but with a symptom-free interval), evolving towards uncontrollable respiratory insufficiency and death, through non-symptomatic forms of fortuitous diagnosis. The x-ray shows micronodular and/or scattered reticulonodular opacities due to alveolar filling (41) (Figures 6, 7). Spirometric data indicate moderate restriction without obstruction. Standard biological function tests do not contribute to diagnosis, except an increase in plasma LDH, which is sometimes sharp, but non-specific (45). Broncho-alveolar lavage (BAL) is presently regarded as the reference diagnostic method, recourse to surgical pulmonary biopsy being more and more rare. BAL yields an opaque, milky fluid suggestive of diagnosis. A PAS-positive material can be found around, as well as inside, the macrophages (Figure 8A). Macrophages are most often enlarged and foamy (Figure 8B). Electron microscopy elicits pseudo-myelin images made of onion bulb arrangement of concentric lipid leaflets with dense bodies at a center as well as fence-like structures corresponding to tubular myelin. These abnormalities are the expression of the storage of both the protein and lipid fractions of the surfactant. In adults, the study of BAL fluid using immunohistochemistry may elicit an increased amount of SP-A, SP-B (46) or SP-D (47). Assessment of $B A L$ lipids by thin-layer chromatography shows an increase in phospholipids and a general profile quite typical for pulmonary surfactant, although different variants such as a decrease in phosphatidyglycerol or an increase in sphingomyelins and in lysophosphatidylcholine may be observed (35). Unfortunately, the pediatric data are presently inconsistent. The lung biopsy, when performed, shows the storage of a granular PAS-positive, protein and lipid, material (Figure 9). The alveoli contain intensely eosinophilic bodies of varied sizes, which represent the cellular debris among which some foamy alveolar macrophages can be seen.

Repeated broncho-alveolar lavage is today the only treatment available for PAP, though makeshift, the disease course ranging from complete remission without sequelae through to end-stage pulmonary fibrosis (48, 49).

Recently, the analysis of CSF2 gene-derived cDNAs from an adult patient with PAP allowed the disclosure of a heterozygous mutation accounting for an isoleucine-threonine substitution, as compared to the canonical sequence of human GM-CSF. In this individual, GM-CSF was not measurable after stimulation of peripheral blood leukocytes and of cells retrieved from broncho-alveolar lavage fluid (50). This case seems to corroborate the present concept of altered surfactant clearance, especially in the light of the knock-out murine models $(22,29)$, and the therapeutic efficacy of recombinant GM-CSF in some patients with PAP (51). However, this isolated observation needs to be regarded as preliminary, because many questions, especially these regarding the actual patient's genotype, remain unanswered.

Adding to the etiopathogenesis of this lung disease, the presence of blocking anti-GM-CSF antibodies was demonstrated in the broncho-alveolar lavage fluids and sera from patients with idiopathic (noncongenital) PAP. These antibodies seem to be absent in the established secondary forms of the disease, in subjects with another type of lung disease and in most healthy controls $(52,53)$. Thus, this observation suggests a high diagnositic value for the presence of anti-GM-CSF antibodies in patients with idiopathic, but not secondary or congenital, PAP. Yet, it remains to be determined whether the presence of anti-GMCSF antibodies is secondary or primary in these patients.

PAP in the neonate. The congenital form of alveolar proteinosis (CAP) has its onset during the neonatal period and its evolution is particularly severe. Prognosis is very poor. This condition translates into neonatal respiratory distress leading to death, which generally occurs during the first year of life, despite maximal medical care. Because precedents in the siblings are not uncommon, and because several consanguineous pedigrees were reported, it seems that the most common pattern of inheritance is autosomal recessive. If one strictly adheres to the diagnostic criteria for alveolar proteinosis, i.e., the storage of both lipid and protein fractions of surfactant, the underlying molecular defect(s) remain unknown, with a possible exception discussed below. Again, this observation seems to point at the GM-CSF (CSF2) signaling pathway (54) and substantiate the original speculations regarding a causal anomaly of surfactant homeostasis (55). In the newborn child, the analysis of BAL fluid and pulmonary biopsy samples were consistent with the diagnosis of PAP. Of note is that the SP-B protein was detected. However, flow cytometry analysis showed a marked deficiency in the $\beta$-chain common to the receptors for GM-CSF and interleukin-3 and interleukin5 (54). Only later, at the age of 20 months (the age at which the patient became oxygen-dependent), was a mutation of the corresponding gene (CSF2RB) demonstrated. This mutation, a $\mathrm{C} \rightarrow \mathrm{A}$ transversion at nucleotide 1835, was identified at the cDNA level. It accounts for the substitution of a threonine for the normal proline residue in position 602 (T602P). Unfortunately, the genomic DNA from the patient and his parents were not analyzed, and this throws doubt upon the definitive validity of these data.

Murine models for alveolar proteinosis. The parallel 
between BAL profile and histological data from patients with alveolar proteinosis, and the murine models with an altered surfactant turnover, is impressive. This concerns not only the $1 / 3 \mathrm{rb} 7^{-1-}$ and $\mathrm{Csfgm}^{-1}$, but also the Sftpd ${ }^{1-}$ knock-outs (see Table 4 for more details). Indeed, two murine models whose phenotype was originally unexpected add to the genetics of alveolar proteinosis. The equivalent of the human disease is replicated by the ablation of the gene encoding the $\beta$ subunit of GM-CSF receptor (/I3rb1\% mice) $(23,31)$, or with the knock out of the gene encoding GMCSF itself ( sfgm $^{-/}$mice) $(22,29,30)$. Indeed, these models are characterized by an important storage of not only protein, but also lipid within the lung. On the other hand, ablation of murine Sftpd was obtained by two research teams $(27,28)$ who published their results almost concomitantly. Sftpd ${ }^{-1-}$ mice have altered pulmonary surfactant homeostasis with progressive storage of lipids, within lung tissue and alveolar space, and develop emphysema $(27,28)$. At present, no deleterious mutations of the corresponding gene (SFTPD) have been reported in any human lung disease. Based on these murine models, CSF2, CSF2RB, and SFTPD provide good candidates for genes mutated in human alveolar proteinosis.

\section{SP-B deficiency}

Complete deficiency of the SP-B surfactant protein is a constitutional disease with neonatal onset, accounting for severe respiratory insufficiency, and was first reported by Nogee and co-workers (56). The spontaneous evolution, based on the cases published to date, is incompatible with prolonged life. This relatively uncommon genetic condition shows an autosomal recessive pattern of inheritance. The authors of the seminal

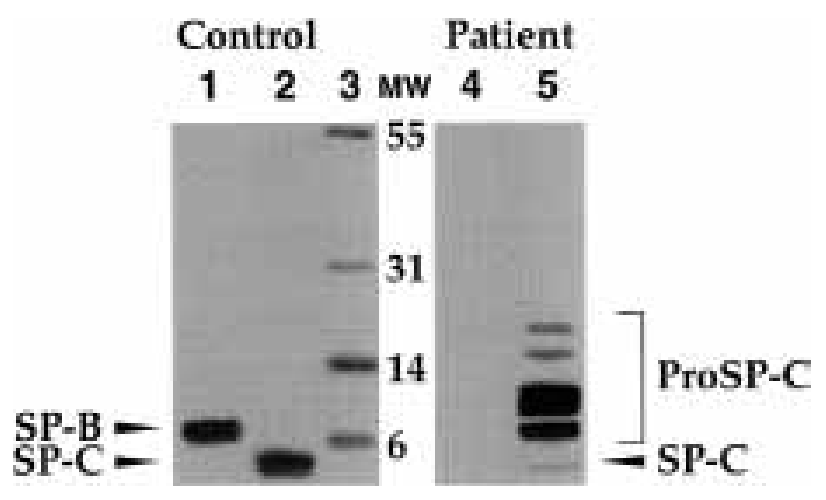

Fig. 10 Quantitative analysis of pulmonary surfactant proteins SP-B, SP-C, and of their precursors (proSP-B and proSPC) by immuno-TLC with use of anti-SP-B and anti-proSP-B (lanes 1, 4), anti-SP-C and anti-proSP-C (lanes 2,5) specific antibodies in the patient (right) as compared to a healthy control (left). The SP-B protein is undetectable in the patient who, in addition, shows incompletely or abnormally processed species of the proSP-C precursor, as compared to the control who shows exclusively mature SP-B and SP-C. Lane 3, molecular weight $(\mathrm{MW})$ marker with corresponding band values indicated in $\mathrm{kDa}$.
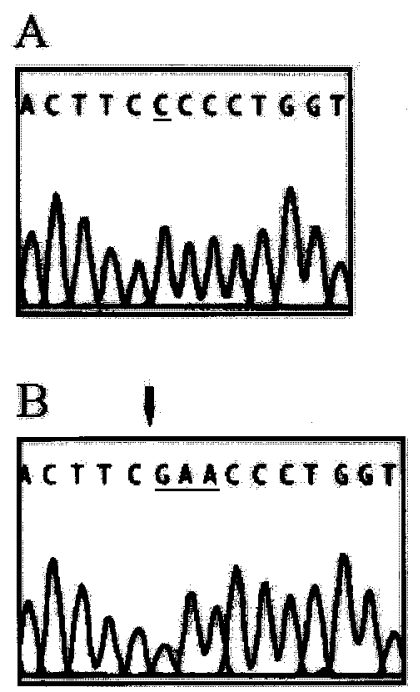

Fig. 11 121ins 2 mutation of the SFTPB gene. The direct nucleotide sequence from the (A) control (homozygous for the wild-type allele) and from the (B) patient's DNA (homozygous for the mutated allele) shows that the 121 ins 2 mutation results form the substitution of a GAA triplet (arrowhead, underlined) to the second residue of a stretch of 5 cytosines (underlined).

paper on the subject reported the case of a child deceased at the age of 5 months following neonatal respiratory distress. His condition was suggestive of alveolar proteinosis, with little or no effect of corticoids or instillation of exogenous surfactants. Near fifty cases of complete SP-B deficiency have been reported since and diagnosis is now facilitated by the knowledge of the molecular basis of the disease. The actual incidence is unknown but seems very low, despite the likelihood that many cases remain undiagnosed (57). The material present in the alveolar space is protein rich, with no sign of storage of phospholipids. In this respect, complete SP-B deficiency clearly differs from CAP. The characterization of alveolar lavage fluid shows not only the absence of the SP-B protein, but the presence of incompletely or abnormally cleaved species of the SP-C propeptide (proSP-C). These findings suggest an important role for the SP-B protein in subcellular trafficking and/or the proteolytic maturation of the SP-C protein or its precursor (Figure 10) (58). The singular observation of complete SP-B deficiency associated with a thorough maturation of proSP-C in a child heterozygous for two null mutations of the SFTPB gene demonstrates that the absence of the SP-B protein, and not a defect in proSP-C processing, is the essential cause of respiratory distress in these children (59).

The ultrastructural study of pulmonary tissue by electron microscopy shows interstitial fibrosis, hyperplasia of type II alveolar cells, desquamated epithelial cells, and (protein) material filling the alveoli (56). The absence of tubular myelin and the scarcity of lamellar bodies are also characteristic for SP-B deficiency 160 , 61). Analysis of lipid turnover in these children using isotopes with an ingestion of $\left[\mathrm{U}-{ }^{13} \mathrm{C}\right]$ glucose does not 
Tab. 5 Molecular pathology of the SFTPB gene.

\begin{tabular}{|c|c|c|c|c|c|c|c|c|c|}
\hline \multirow{2}{*}{$\begin{array}{l}\text { Reference } \\
\text { nomenclature }^{a}\end{array}$} & \multirow{2}{*}{$\begin{array}{l}\text { Alternative } \\
\text { designation }^{\mathrm{b}}\end{array}$} & \multirow{2}{*}{$\begin{array}{l}\text { Mutation } \\
\text { type }\end{array}$} & \multirow{2}{*}{$\begin{array}{l}\text { Molecular } \\
\text { significance }\end{array}$} & \multirow[t]{2}{*}{ Exon } & \multirow{2}{*}{$\begin{array}{l}\text { Patient } \\
\text { genotype }\end{array}$} & \multicolumn{2}{|c|}{ SP-B protein } & \multirow{2}{*}{$\begin{array}{l}\text { Clinical } \\
\text { pheno- } \\
\text { type }\end{array}$} & \multirow[t]{2}{*}{ Ref. } \\
\hline & & & & & & $\begin{array}{l}\text { BAL or TA } \\
\text { (ELISA/ } \\
\text { Western- } \\
\text { blot) }\end{array}$ & $\begin{array}{l}\text { Immuno- } \\
\text { histo- } \\
\text { chemistry } \\
\text { (anti-SP-B } \\
\text { labeling) }\end{array}$ & & \\
\hline T52C & L13P & Substitution & MS & 1 & $\begin{array}{l}\mathrm{T} 52 \mathrm{C} / 1549 \mathrm{C} \\
\rightarrow \mathrm{GAA}\end{array}$ & - & - & Lethal & (66) \\
\hline G441A & W39X & Substitution & NS & 2 & $\begin{array}{l}\text { G441A/1549C } \\
\rightarrow \text { GAA }\end{array}$ & ND & - & Lethal & (66) \\
\hline 457delC & $45 \mathrm{delC}$ & Deletion & FS & 2 & $\begin{array}{l}457 \text { delC/1549C } \\
\rightarrow \text { GAA }\end{array}$ & - & ND & Lethal & (59) \\
\hline T469C & C49R & Substitution & MS & 2 & $\begin{array}{l}\mathrm{T} 469 \mathrm{C} / 1549 \mathrm{C} \\
\rightarrow \mathrm{GAA}\end{array}$ & - & ND & Unknown & (66) \\
\hline G504A & W60X & Substitution & NS & 2 & G504A/G504A & - & - & Lethal & (66) \\
\hline A523G & $\mathrm{IVS} 2+4 \mathrm{~A} \rightarrow \mathrm{G}$ & Substitution & $\begin{array}{l}\text { Exon skipping } \\
\text { (FS) }\end{array}$ & 2 & A523G/A523G & - & - & Lethal & (66) \\
\hline 1454delA & IVS3-2delA & Deletion & $\begin{array}{l}\text { Exon skipping) } \\
\text { (in-frame) }\end{array}$ & 4 & $\begin{array}{l}\text { 1454delA/1549C } \\
\rightarrow \text { GAA }\end{array}$ & ND & - & Lethal & (66) \\
\hline T1486G & C100G & Substitution & MS & 4 & $\begin{array}{l}\mathrm{T} 1486 \mathrm{G} / 1549 \mathrm{C} \\
\rightarrow \mathrm{GAA}\end{array}$ & ND & $\begin{array}{l}+(\text { very } \\
\text { reduced })\end{array}$ & Unknown & (66) \\
\hline $1549 \mathrm{C} \rightarrow \mathrm{GAA}$ & 121 ins2 & $\begin{array}{l}\text { Deletion/ } \\
\text { insertion }\end{array}$ & FS & 4 & $\begin{array}{l}1549 \mathrm{C} \rightarrow \mathrm{GAA} / \\
1549 \mathrm{C} \rightarrow \mathrm{GAA}\end{array}$ & - & - & Lethal & $\begin{array}{l}(60,63- \\
65,67)\end{array}$ \\
\hline 1552delC & $122 \mathrm{delC}$ & Deletion & FS & 4 & $\begin{array}{l}\text { 1552delC/1549C } \\
\rightarrow \text { GAA }\end{array}$ & ND & - & Lethal & (68) \\
\hline 1553delT & 122delT & Deletion & FS & 4 & $\begin{array}{l}\text { 1553delT/ } \\
\text { 1553delT }\end{array}$ & - & - & Lethal & (69) \\
\hline 2415-2416insAA & 134ins2 & Insertion & FS & 5 & $\begin{array}{l}\text { 2415-2416insAA/ } \\
1549 \mathrm{C} \rightarrow \text { GAA }\end{array}$ & ND & - & Lethal & (70) \\
\hline G2417A & G135S & Substitution & MS & 5 & $\mathrm{G} 2417 \mathrm{~A} / ?$ & $\begin{array}{l}- \text { (D 38), then } \\
+(D \text { 106) }\end{array}$ & $+(D 72)$ & Survival & (71) \\
\hline G2479T & $\begin{array}{l}{[\mathrm{r} .479 \mathrm{~g} \rightarrow \mathrm{u} ;} \\
479 \mathrm{~g} \rightarrow \mathrm{u} \\
\left.+478 \_596 d e l\right]\end{array}$ & Substitution & $\begin{array}{l}\text { Isosemantic } \\
\text { mutation and/ } \\
\text { or splicing } \\
\text { anomaly with } \\
\text { FS }\end{array}$ & 5 & G2479T/G2479T & ND & $\begin{array}{l}+(\text { very } \\
\text { reduced) }\end{array}$ & $\begin{array}{l}\text { Prolonged } \\
\text { survival }\end{array}$ & (72) \\
\hline G2913A & $224 \mathrm{G} \rightarrow \mathrm{A}$ & Substitution & $\begin{array}{l}\text { Isosemantic } \\
\text { mutation and/ } \\
\text { or splicing } \\
\text { anomaly }\end{array}$ & 6 & $\begin{array}{l}\text { G2913A/1549C } \\
\rightarrow \text { GAA }\end{array}$ & - & ND & Lethal & (66) \\
\hline T4377C & $\mathrm{C} 235 \mathrm{R}$ & Substitution & MS & 7 & $\begin{array}{l}\text { T4377C/1549C } \\
\rightarrow \text { GAA }\end{array}$ & - & $\begin{array}{l}+(\text { very } \\
\text { reduced })\end{array}$ & Lethal & (66) \\
\hline С4380T & $\mathrm{R} 236 \mathrm{C}$ & Substitution & NS & 7 & $\begin{array}{l}\mathrm{C} 4380 \mathrm{~T} / 1549 \mathrm{C} \\
\rightarrow \mathrm{GAA}\end{array}$ & - & $\begin{array}{l}+(\text { very } \\
\text { reduced })\end{array}$ & Lethal & (73) \\
\hline C4418A & $\mathrm{C} 248 \mathrm{X}$ & Substitution & MS & 7 & $\begin{array}{l}\mathrm{C} 4418 \mathrm{~A} / 1549 \mathrm{C} \\
\rightarrow \mathrm{GAA}\end{array}$ & - & - & $\begin{array}{l}\text { Transplan- } \\
\text { tation }\end{array}$ & (66) \\
\hline C4428T & $\mathrm{R} 252 \mathrm{C}$ & Substitution & MS & 7 & $\mathrm{C} 4428 \mathrm{~T} / \mathrm{C} 4428 \mathrm{~T}$ & - & $\begin{array}{l}+(\text { very } \\
\text { reduced })\end{array}$ & Unknown & (66) \\
\hline 6109-6110insCCC & GT343-P344insF & Insertion & $\begin{array}{l}\text { Insertion of } \\
\text { one amino acid }\end{array}$ & 9 & 6109insCCG/6109insCCG & - & $\begin{array}{l}+(\text { very } \\
\text { reduced })\end{array}$ & Lethal & (66) \\
\hline 6114-6125del & G345-T348del & Deletion & $\begin{array}{l}\text { Deletion of } \\
4 \text { amino acids }\end{array}$ & 9 & $\begin{array}{l}\text { 6114-6125del/ } \\
1549 \mathrm{C} \rightarrow \mathrm{GAA}\end{array}$ & - & - & Lethal & (66) \\
\hline
\end{tabular}

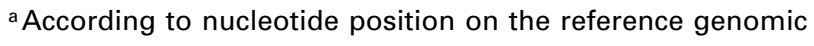
sequence (16), and the recommendations for a nomenclature of human gene mutations (74). ${ }^{b}$ According to codon numbering and/or consequences upon translation, or splicing. BAL: broncho-alveolar lavage; D: day; FS: frameshift; MS: missense; NS: nonsense; ND: not determined; TA: tracheal aspirate; -: negative; +: positive. significantly depart from healthy controls, which supports that it is a near pure protein abnormality without any consequences for lipid homeostasis, thereby contrasting with alveolar proteinosis (62). Finally, akin to 
congenital proteinosis, plasma LDH is extremely high, reflecting the magnitude of damage to the respiratory epithelium.

A frameshift mutation of the SFTPB gene $(C \rightarrow$ GAA, codon 121), now commonly referred to as 121 ins 2 , represents a non-negligible fraction of the molecular pathology of the SFTPB gene in association with SP-B deficiency $(59,60,63-67)$ (see Table 5 for details regarding the molecular pathology of the SFTPB gene). The prevalence of a given mutation could suggest the existence of a founder effect, or a mutation hot spot (Figure 11), although no obviously unstable nucleotide structure seems to associate with this lesion of the gene. The patients homozygous for the 121 ins 2 mutation show a uniform disease course: severe respiratory insufficiency with alveolar infiltrates on the $x$-ray in the first hours of life, little or no improvement following administration of exogenous surfactant or glucocorticoid, and requirement for extracorporeal life support. Death occurs during the first weeks or months of life, survival being possible only at the cost of lung transplantation (75). The 121ins2 heterozygotes have normal lung function (76), in contrast to the knock-out murine models (77) (see below).

Murine model for SP-B deficiency. Among the two genes encoding the hydrophobic proteins, only the Sftpb gene has been knocked-out in mice to date (see Table 4 for details). Homozygous ( $\mathrm{ftph}^{-1-}$ ) mice die as neonates due to severe respiratory distress (26). The pathological characterization of their lungs shows the complete absence of SP-B protein, and, as in man, the presence of immature or abnormally processed SP-C (proSP-C), and the absence of mature SP-C. Heterozygotes have a defect in pulmonary compliance and
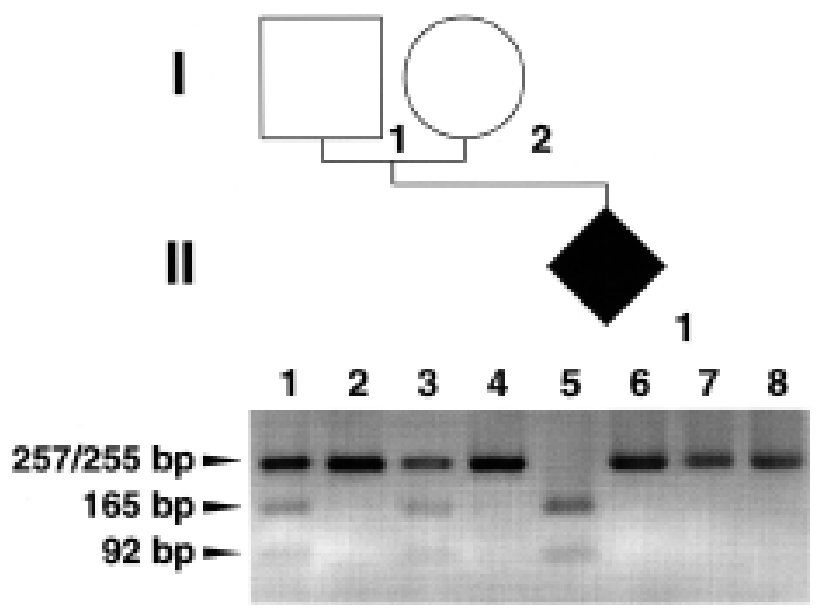

Fig. 12 Assessment of the 121 ins 2 mutation by PCR amplification of exon 4 and endonuclease restriction using Sful. This figure shows the gel electrophoresis of the PCR products restricted (odd lanes) and unrestricted (even lanes) from the fa ther $(I-1$; lanes 1,2$)$, the mother $(I-2 ;$ lanes 3,4$)$, the proband (II1 ; lanes 5, 6), and the wild-type control (lanes 7, 8). The corresponding band sizes are indicated in base pairs (bp). From analysis of the electrophoretic pattern, the proband is homozygous for the 121 ins 2 mutation which he has inherited from his heterozygous parents. show excess dead space (77). Briefly, these animals resemble the human disease, except for slight changes in heterozygotes, and provide a suitable experimental model for SP-B deficiency.

Diagnosing SP-B deficiency. Today, diagnosing SP-B deficiency is feasible at the molecular level. Molecular diagnosis is facilitated by the existence of a common mutation (121ins2) which generates a restriction endonuclease cleavage site (Figure 12). Assessment of this mutation must be performed in any term or nearterm born infant who shows signs of hyaline membrane disease which do not evolve favourably after 5 days of life after a congenital pulmonary infection by atypical micro-organisms (enteroviruses, mycoplasma, chlamydia) and congenital heart disease have been ruled out as a cause of hypoxemia or pulmonary hypertension. This diagnostic strategy could be challenged since a number of distinct STFPB gene mutations are now to be found in the literature. Such allelic heterogeneity is in line with the general model of genetic diseases proceeding through haplo-insufficiency. These mutations are quite homogeneously scattered throughout the gene, let alone the regulatory regions (promotor region, $5^{\prime}-$ and $3^{\prime}$ UTR) (Table 5) and are point mutations (including nonsense, mis-sense and splice lesions) as well as short frameshift insertions or deletions (66).

Milder forms of $S P-B$ deficiency. Beside complete SP-B protein deficiency, partial $(66,72,73)$ or transient (71) deficiencies have been reported. These deficiencies also lie in the framework of SFTPB. In particular, several mutations underscoring partial deficiency were reported, correlating with a complete absence of the mature SP-B protein in tracheal aspirate, positive staining in type II alveolar cells for the intermediary $26-\mathrm{kDa}$ proSP-B species, and positive but faint staining for SP$\mathrm{B}$ within type II alveolar cells and the alveolar space. This relates in particular to the T343-P344insP and missense C100G, C235R, R236C mutations, all of which respect the reading frame $(66,73)$. More recently, a homozygous isosemantic mutation generating an aberrant $3^{\prime}$ (acceptor) splice site competing with the wild-type site (G2479T) (see Table 5) was observed in two unrelated infants of the same ethnic background (French Canadians) (72). This mutation accounts for a decrease in mature SP-B synthesis and co-existence with an aberrant protein. Although the disease is severe and of neonatal onset, the associated phenotype is not that of a 121 ins 2 mutation homozygote, since it is compatible with prolonged survival. Analysis of pulmonary tissue from one of the two infants who underwent lung transplantation shows substantial decrease of the SP-B protein (between 12 and $16 \%$ of normal ranges).

Conclusions on SP-B deficiency. The molecular consequences of SFTPB mutations can be found at any of the steps of gene expression, such as absence of the mature messenger (78), abnormality of transport/routing of the protein, abnormality of processing of the precursor species, or synthesis of a partially or completely non-functional mature protein. Although the synthesis 
of an abnormal mature SP-B protein without associated quantitative deficiency has not been shown in man, transgenic murine models with proteins that are deficient for the establishment of inter- or intra-chain disulfide bonds, show the actual possibility of such a phenomenon in man $(79,80)$.

Partial SP-B deficiencies can account for unusual prolonged respiratory distress in the newborn child or for a chronic intractable and apparently unexplained lung disease in the toddler. The immunohistochemical study of pulmonary tissue (lung biopsy) with labeling of the surfactant proteins will then permit the diagnosis. In addition, these observations highlight the notion of a threshold SP-B protein level compatible with normal lung function (generation of tubular myelin, proSP-C processing, surface tension of the monolayer, etc.). Sftph ${ }^{+-}$heterozygous murine models, in which one can observe gene dosage effect (Sftpb messenger and corresponding protein levels decreased by half), present with minor pulmonary function abnormalities (see below) (77), whereas SFTPB 121ins2/wt heterozygous humans have normal lung function (76). Therefore, if there is a threshold SP-B protein level, this threshold is expected to be different in man and mice, and the difference probably resides in genetic loci that are not allelic to SFTPB. This is clearly an opening towards oligogenic, or multigenic inheritance. Indeed, it is possible that individuals that are carriers of a mutation reducing the production of SP-B protein are at risk of developing lung disease, provided that an additional factor (mutation at another locus, secondary disease) happens to alter SP-B protein metabolism. Such a hypothesis was set forth as an explanation for a transient complete SP-B deficiency in an individual heterozygous for a mis-sense mutation (G135S, exon $5)$, inherited from the healthy mother, without any sequence deviation identified on the paternal allele (71).

\section{Other abnormalities of surfactant}

Recently, a term-born child with an apparently unexplained neonatal respiratory distress was reported, which did not meet the diagnostic criteria for either alveolar proteinosis or SP-B deficiency. In this child, transmission electron microscopy showed a deficiency in lamellar bodies within type II alveolar cells (81). Although this observation is clearly a precedent, it mirrors the observed heterogeneity in the protein profiles in children (familial and sporadic cases) with respiratory distress which led to the exploration of a possible primary abnormality of pulmonary surfactant, and one might speculate that a large number of nosologically distinct entities remain to be identified.

\section{Strategy for Ascertainment of Infants with Suspected Abnormalities of Surfactant}

The molecular basis of alveolar proteinosis in man remains to be elucidated. Practically, the children showing primary or unexplained respiratory distress possi- bly consistent with alveolar proteinosis or SP-B deficiency are justifiable of the same diagnostic chart. Based on the prevalence of a particular mutation of the SFTPB gene ( $1549 \mathrm{C} \rightarrow \mathrm{GAA}$, or 121 ins 2 mutation) in this group of patients, it seems completely justified to assess its presence in all term-born children with unexplained respiratory distress using molecular screening (Figure 12), even prior to the completion of the biochemical analysis of surfactant. Indeed, this mutation generates a recognition site for restriction endonucleases (Sful, Taql). Assessment of this mutation must be carried out in emergency, owing to the extremely severe phenotype entailed by complete SP-B deficiency, and because of the very short time interval for a possi-

\section{Family 1}

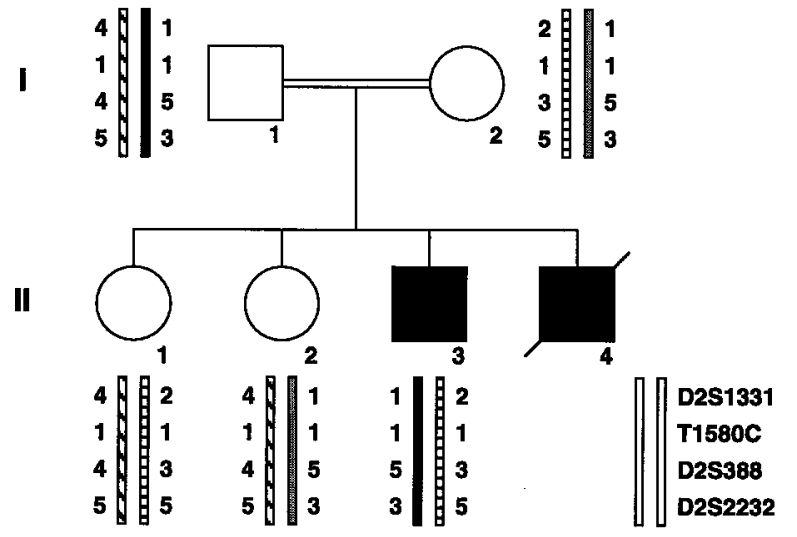

Family 2

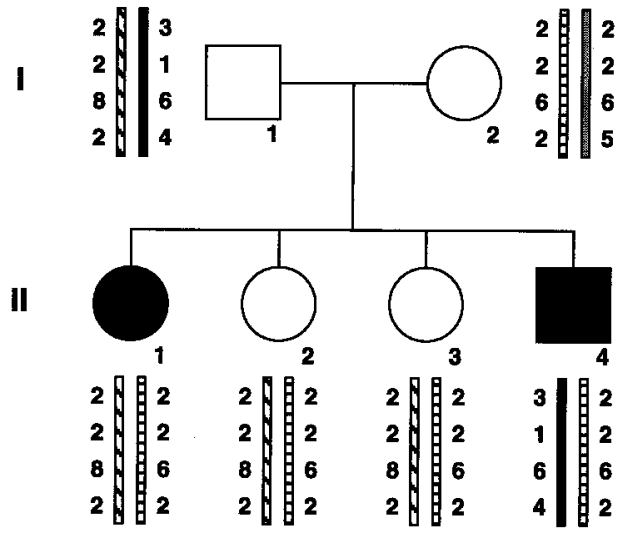

Fig. 13 Segregation analysis of SFTPB locus markers in two potentially informative families. The filled symbols designate effected individuals. Alleles at loci D2S1331, D2S388, D2S2232 (82) and the T1580C substitution polymorphism (83) are indicated from the telomere towards the centromere, from top to bottom. The haplotypes were set up based on the least number of recombination events. Family 1: the presence of two distinct haplotypes in the proband of this consanguineous pedigree constitutes a near-formal exclusion of the locus, considering the rarity of SP-B deficiency. Family 2: the presence of two non-haploidentical affected subjects, and evidence of common haplotypes shared by both an affected individual (I-1) and his healthy sisters (II-2, II-3) again allow exclusion of the SFTPB locus. 
ble pulmonary graft. The segregation analysis of polymorphic DNA markers can occasionally prove very useful when formal exclusion of the SFTPB locus allows to spare the tedious molecular sequencing of the 11 exons and promotor region of the gene. Such segregation analyses can be carried out in potentially informative families such as consanguineous pedigrees, or if there exists an affected sibling with an available source of DNA (Figure 13). Although assessment for the 121 ins 2 mutation is justified outright, this diagnostic test should not hinder a detailed biochemical characterization of surfactant before the molecular study is resumed. Such biochemical characterization is ideally carried out from broncho-alveolar lavage fluid and consists of the assessment of the four surfactant proteins using ELISA (SP-B, SP-D, SP-A) and immuno-thin-layer chromatography, SDS-PAGE or Western blotting (SP-B, SP-C), with aid of antibodies (Figure 10). In addition, the native and/or aberrant species of SP-C are to be identified using an anti-proSP-C antibody, notably in the case of an SP-B deficiency. This analysis should be performed as distantly as possible from any instillation of exogenous surfactant. The recent demonstration of SP-B and SP-C assessment using high-performance liquid chromatography (HPLC) might rapidly expand this fast-moving field of specialized clinical chemistry (84). Pulmonary biopsy followed by immunohisto- chemistry is less and less justified, although still informative, especially in the cases with partial SP-B deficiency, or when there are technical artefacts due to the presence of cell debris in broncho-alveolar lavage fluid. So far, only two or three specialized laboratories in the world are of the right calibre to complete this kind of study. At this point, there are no consensus diagnostic guide-lines. The molecular exploration of protein deficiencies other than SP-B's are exclusively research protocols, because no mutation of the SFTPC, SFTPD, SFTPA 1/2 genes has been shown in man. In the absence of a well characterized surfactant protein deficiency, the protein can be present although abnormal, and could be recognized by the antibodies. On the contrary, absence of a clear protein deficiency can be consistent with a primary abnormality of surfactant metabolism. Each laboratory will have guide-lines according to the specialized techniques they handle best. According to some authors, the GM-CSF signaling pathway can be explored, e.g., with the quantitation of the $\alpha$ and $\beta$ subunits of GM-CSF receptor using flow cytometry $(54,85)$. The assessment of GM-CSF's affinity for its receptor can be performed using binding studies (54), and the CSF2, CSF2RA, and CSF2RB messengers can be analyzed for a mutation (86). This ascertainment strategy is shown in Figure 14 and details concerning the biological samples appear in Table 6.

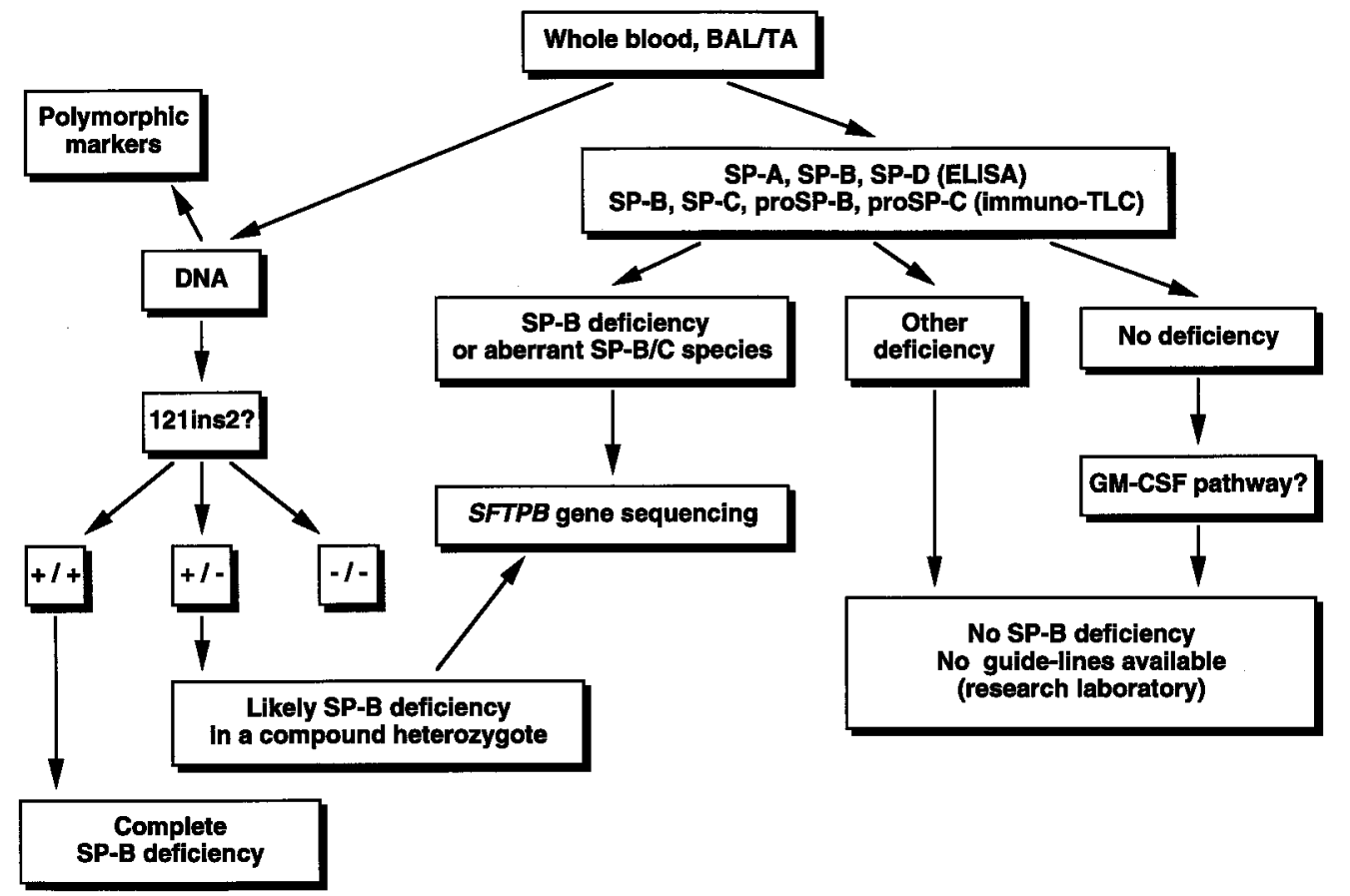

Fig. 14 General scheme for diagnostic ascertainment of a child showing unexplained respiratory distress with suspicion of a primitive abnormality of pulmonary surfactant. The simultaneous analysis of DNA, screening for the $121 \mathrm{ins} 2 \mathrm{mu}-$ tation, and of bronchoalveolar lavage (BAL) fluid or tracheal aspirate (TA) for the SP-B protein and precursor protein proSP-C constitute the first step. The diagnosis of SP-B deficiency is above all biochemical (absence or traces of SP-B protein, aberrant and/or immature SP-C/proSP-C species), and it will be corroborated by evidence for a homozygous (especially 121ins2/121ins2) or compoundly heterozygous SFTPB gene mutation. Assessment of a possible deficiency in another surfactant protein, or of a possible primitive abnormality of surfactant metabolism at large (GM-CSF pathway) needs specialized research laboratory. The place of pulmonary biopsy, non rarely carried out, remains to be determined (post mortem diagnosis, BAL analysis impossible or inconclusive, abnormality of SP-B excretion, analysis of gene messengers). 
Tab. 6 Biological samples and specialized investigation of an unexplained respiratory distress syndrome with a suspicion of a primary (non-HMD) abnormality of surfactant.

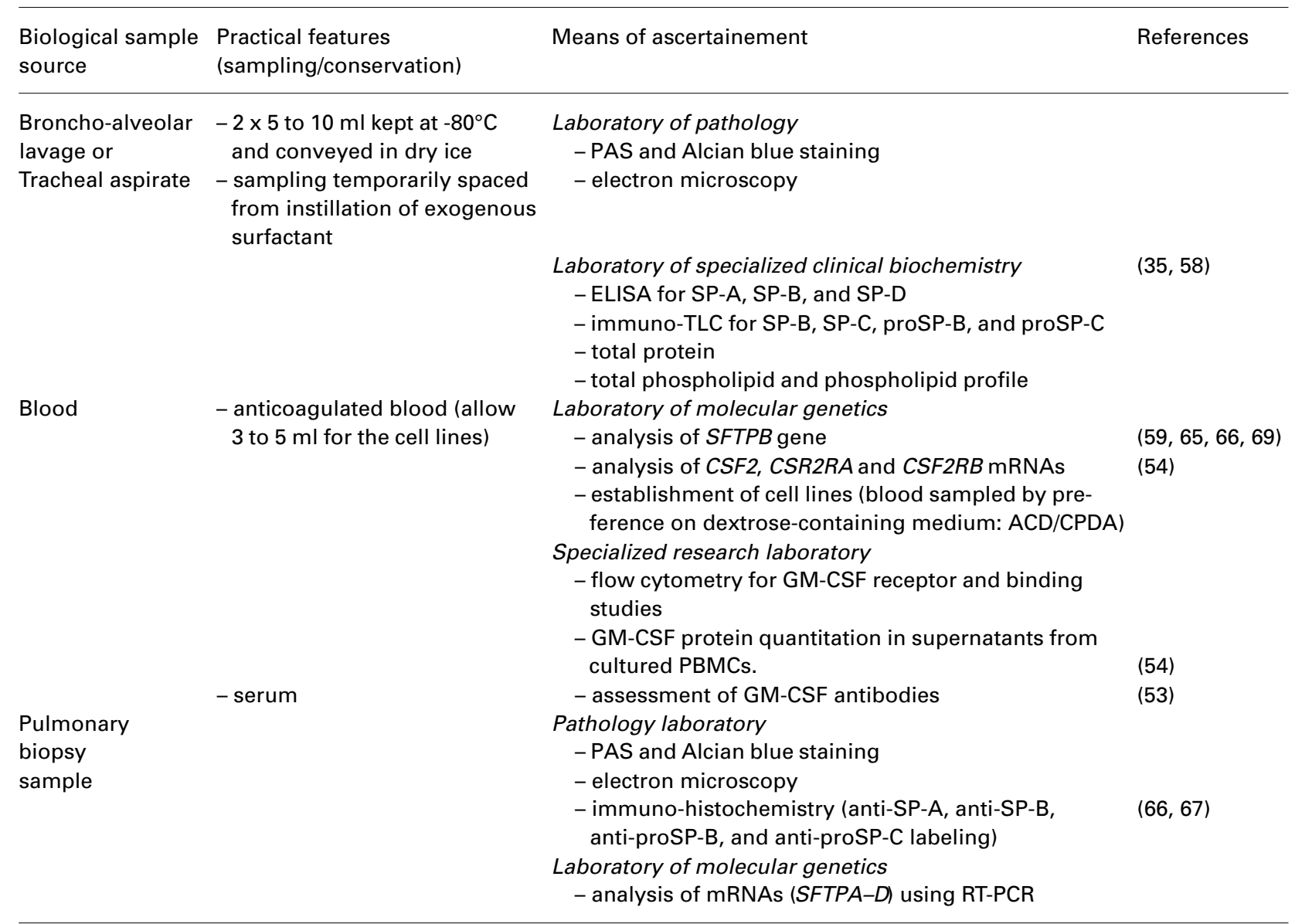

TLC: thin-layer chromatography; PBMCs: peripheral mononucleated cells

\section{Conclusion}

Beside hyaline membrane disease of the preterm neonate, discrete nosologic entities accounting for a number of cases of respiratory distress in the neonate, child or adult are currently being identified. Alveolar proteinosis, the genetic basis of which remains to be determined, is a heterogeneous disease cluster from which surfactant protein B deficiency has been clearly singled out. This is presently regarded as a distinct primitive abnormality of surfactant metabolism, due to the absence of lipid storage within the alveoli. The allelic heterogeneity observed so far could be consistent with a heterogeneity in both the clinical translation and biochemical or pathological findings. The bulk of data presently available suggest substantial complexity of surfactant metabolism, especially regarding the relationship between SP-B protein and phospholipids, and SP-B's involvement in the generation of a thoroughly processed SP-C protein. As for the GM-CSF signaling pathway, the diagnostic value of anti-GM-CSF antibodies and the knock-out murine models indicate a morethan-anecdotal involvement. However, the specific pathophysiological mechanisms involving GM-CSF in human disease remain obscure. Whatever the case, the research into this cytokine seems promising because of the possible therapeutic consequences such as replacement therapy and bone marrow transplantation.

Analysis of genes involved in the pulmonary surfactant metabolism opens a number of new perspectives in terms of etiological diagnosis and the specific care such as differentiated treatment or genetic counseling. In addition, these genes, based on polymorphisms and other minor alterations, may also affect the clinical course of genetically and/or environmentally determined conditions where surfactant abnormalities were noted (asthma, cystic fibrosis, etc.) and thus act as modifying genes. Conversely, they might confer a certain risk for discrete lung diseases such as HMD and thereby act as susceptibility genes. Population genetics and the study of population isolates will hopefully bring some of the genes to light. Much remains to be done and only an integrated clinical biological approach will enable satisfactory answers to our questions on the etiopathogenesis of this novel cluster of lung diseases.

\section{References}

1. Power JHT, Doyle IR, Davidson K, Nicholas TE. Ultrastructural and protein analysis of surfactant in the Australian lungfish Neoceratodus forsteri: evidence for conservation 
of composition for 300 million years. J Exp Biol 1999; 202:2543-50.

2. Pryhuber GS. Regulation and function of pulmonary surfactant protein B. Mol Genet Metab 1998; 64:217-28.

3. Creuwels LAJM, van Golde LMG, Haagsman HP. The pulmonary surfactant system: biochemical and clinical aspects. Lung 1997; 175:1-39.

4. Hamvas A. Surfactant protein B deficiency: insights into inherited disorders of lung cell metabolism. Curr Probl Pediatr 1997; 27:329-45.

5. Malhotra R, Haurum J, Thiel S, Sim RB. Interaction of C1q receptor with lung surfactant protein $A$. Eur $\mathrm{J}$ Immunol 1992; 22:1437-45.

6. Nepomuceno RR, Henschen-Edman AH, Burgess WH, Tenner AJ. cDNA cloning and primary structure analysis of $\mathrm{C} 1 \mathrm{qR}(\mathrm{P})$, the human $\mathrm{C} 1 \mathrm{q} / \mathrm{MBL} / \mathrm{SPA}$ receptor that mediates enhanced phagocytosis in vitro. Immunity 1997; 6:119-29.

7. Kresch MJ, Christian C, Lu H. Isolation and partial characterization of a receptor to surfactant protein A expressed by rat type Il pneumocytes. Am J Respir Cell Mol Biol 1998; 19:216-25.

8. Eggleton $P$, Reid KBM. Lung surfactant proteins involved in innate immunity. Curr Opin Immunol 1999; 11:28-33.

9. Holmskov U, Lawson P, Teisner B, Tornøe I, Willis AC, Morgan $C$, et al. Isolation and characterization of a new member of the scavenger receptor superfamily, glycoprotein340 (gp-340), as a lung surfactant protein-D binding molecule. J Biol Chem 1997; 272:13743-9.

10. Sastry K, Ezekowitz RA. Collectins: pattern recognition molecules involved in first line host defense. Curr Opin Immunol 1993; 5:59-66.

11. Mason RJ, Greene K, Voelker DR. Surfactant protein A and surfactant protein $D$ in health and disease. Am J Physiol 1998; 275:L1-13.

12. Madan $T$, Kishore $U$, Shah $A$, Eggleton $P$, Strong $P$, Wang JY, et al. Lung surfactant proteins $A$ and $D$ can inhibit specific IgE binding to the allergens of Aspergillus fumigatus and block allergen-induced histamine release from human basophils. Clin Exp Immunol 1997; 110:241-9.

13. Wang J-Y, Shieh C-C, You P-F, Lei H-Y, Reid KBM. Inhibitory effect of pulmonary surfactant proteins $A$ and $D$ on allergen-induced lymphocyte proliferation and histamine release in children with asthma. Am J Respir Crit Care Med 1998; 158:510-8.

14. Chroneos ZC, Abdolrasulnia R, Whitsett JA, Rice WR, Shepherd VL. Purification of a cell-surface receptor for surfactant protein A. J Biol Chem 1996; 271:16375-83.

15. Vamvakopoulos NC, Modi WS, Floros J. Mapping the human pulmonary surfactant-associated protein $B$ gene (SFTP3) to chromosome $2 \mathrm{p} 12 \rightarrow \mathrm{p} 11.2$. Cytogenet Cell Genet 1995; 68:8-10.

16. Pilot-Matias TJ, Kister SE, Fox JL, Kropp K, Glasser SW, Whitsett JA. Structure and organization of the gene encoding human pulmonary surfactant proteolipid SP-B. DNA 1989; 8:75-86.

17. Hawgood S, Latham D, Borchelt J, Damm D, White T, Benson $\mathrm{B}$, et al. Cell-specific posttranslational processing of the surfactant-associated protein SP-B. Am J Physiol 1993; 264:L290-9.

18. Fisher JH, Emrie PA, Drabkin HA, Kushnik T, Gerber M, Hofmann $T$, et al. The gene encoding the hydrophobic surfactant protein SP-C is located on $8 \mathrm{p}$ and identifies an EcoRI RFLP. Am J Hum Genet 1988; 43:436-41.

19. Glasser SW, Korfhagen TR, Perme CM, Pilot-Matias TJ, Kister SE, Whitsett JA. Two SP-C genes encoding human pulmonary surfactant proteolipid. J Biol Chem 1988; 263:10326-31.
20. Curstedt T, Johansson J, Persson P, Eklund A, Robertson B, Löwenadler $B$, et al. Hydrophobic surfactant-associated polypeptides: SP-C is a lipopeptide with two palmitoylated cysteine residues, whereas SP-B lacks covalently linked fatty acyl groups. Proc Natl Acad Sci USA 1990; 87:2985-9.

21. Ikegami $M$, Jobe AH. Surfactant protein metabolism in vivo. Biochim Biophys Acta 1998; 1408:218-25.

22. Dranoff G, Crawford AD, Sadelain M, Ream B, Rashid A, Bronson RT, et al. Involvement of granulocyte-macrophage colony-stimulating factor in pulmonary homeostasis. Science 1994; 264:713-6.

23. Nishinakamura $R$, Nakayama $N$, Hirabayashi $Y$, Inoue $T$, Aud D, McNeil T, et al. Mice deficient for the IL-3/GMCSF/IL-5 $\beta$ c receptor exhibit lung pathology and impaired immune response, while $\beta_{\mathrm{IL} 3}$ receptor-deficient mice are normal. Immunity 1995; 2:211-22.

24. Korfhagen TR, Bruno MD, Ross GF, Huelsman KM, Ikegami $M$, Jobe $A H$, et al. Altered surfactant function and structure in SP-A gene targeted mice. Proc Natl Acad Sci USA1996; 93:9594-9.

25. Ikegami M, Korfhagen TR, Bruno MD, Whitsett JA, Jobe $\mathrm{AH}$. Surfactant metabolism in surfactant protein A-deficient mice. Am J Physiol 1997; 272:L479-85.

26. Clark JC, Wert SE, Bachurski CJ, Stahlman MT, Stripp BR, Weaver TE, et al. Targeted disruption of the surfactant protein B gene disrupts surfactant homeostasis, causing respiratory failure in newborn mice. Proc Natl Acad Sci USA 1995; 92:7794-8.

27. Botas C, Poulain F, Akiyama J, Brown C, Allen L, Goerke J, et al. Altered surfactant homeostasis and alveolar type II cell morphology in mice lacking surfactant protein D. Proc Natl Acad Sci USA 1998; 95:11869-74.

28. Korfhagen TR, Sheftelyevich V, Burhans MS, Bruno MD, Ross GF, Wert SE, et al. Surfactant protein-D regulates surfactant phospholipid homeostasis in vivo. J Biol Chem 1998; 273:28438-43.

29. Stanley E, Lieschke GJ, Grail D, Metcalf D, Hodgson G, Gall JAM, et al. Granulocyte/macrophage colony-stimulating factor-deficient mice show no major perturbation of hematopoiesis but develop a characteristic pulmonary pathology. Proc Natl Acad Sci USA 1994; 91:5592-6.

30. Ikegami M, Ueda T, Hull W, Whitsett JA, Mulligan RC, Dranoff G, et al. Surfactant metabolism in transgenic mice after granulocyte macrophage-colony stimulating factor ablation. Am J Physiol 1996; 270:L650-8.

31. Robb L, Drinkwater CC, Metcalf D, Li R, Köntgen F, Nicola $N A$, et al. Hematopoietic and lung abnormalities in mice with a null mutation of the common $\beta$ subunit of the receptors for granulocyte-macrophage colony-stimulating factor and interleukins 3 and 5. Proc Natl Acad Sci USA 1995; 92:9565-9.

32. Clements JA, Avery ME. Lung surfactant and neonatal respiratory distress syndrome. Am J Respir Crit Care Med 1998; 157:S59-66.

33. Stoll BJ, Kliegman RM. Hyaline membrane disease (respiratory distress syndrome). In: Behrman RE, Kliegman RM, Jenson HB, editors. Nelson textbook of pediatrics, 16 th edition. Philadelphia: WB Saunders Company, 2000: 498-505.

34. Robertson B, Halliday HL. Principles of surfactant replacement. Biochim Biophys Acta 1998; 1408:346-61.

35. Griese M. Pulmonary surfactant in health and human lung diseases: state of the art. Eur Respir J 1999; 13:1455-76.

36. Myrianthopoulos NC, Churchill JA, Baszynski AJ. Respiratory distress syndrome in twins. Acta Genet Med Gemellol (Roma) 1971; 20:199-204.

37. Floros J, Veletza SV, Kotikalapudi P, Krizkova L, Karinch AM, Friedman C, et al. Dinucleotide repeats in the human 
surfactant protein-B gene and respiratory-distress syndrome. Biochem J 1995; 305:583-90.

38. Kala P, Ten Have T, Nielsen H, Dunn M, Floros J. Association of pulmonary surfactant protein A (SP-A) gene and respiratory distress syndrome: interaction with SP-B. Pediatr Res 1998; 43:169-77.

39. Rämet M, Haataja R, Marttila R, Floros J, Hallman M. Association between the surfactant protein A (SP-A) gene locus and respiratory-distress syndrome in the Finnish population. Am J Hum Genet 2000; 66:1569-79.

40. Rosen SH, Castleman B, Liebow AA. Pulmonary alveolar proteinosis. N Engl J Med 1958; 258:1123-42.

41. Wang BM, Stern EJ, Schmidt RA, Pierson DJ. Diagnosing pulmonary alveolar proteinosis - a review and an update. Chest 1997; 111:460-6.

42. Mahut B, Delacourt C, Scheinmann P, de Blic J, Mani TM, Fournet J-C, et al. Pulmonary alveolar proteinosis: experience with eight pediatric cases and a review. Pediatrics 1996; 97:117-22.

43. Davidson JM, Macleod MW. Pulmonary alveolar proteinosis. Br J Dis Chest 1969; 63:13-28.

44. Prakash UBS, Barham SS, Carpenter HA, Dines DE, Marsh HM. Pulmonary alveolar phospholipoproteinosis: experience with 34 cases and a review. Mayo Clin Proc 1987; 62:499-518.

45. Drent M, Cobben NAM, Henderson RF, Wouters EFM, van Dieijen-Visser M. Usefulness of lactate dehydrogenase and its isoenzymes as indicators of lung damage or inflammation. Eur Respir J 1996; 9:1736-42.

46. Doyle IR, Davidson KG, Barr HA, Nicholas TE, Payne K, Pfitzner J. Quantity and structure of surfactant proteins vary among patients with alveolar proteinosis. Am J Respir Crit Care Med 1998; 157:658-64.

47. Crouch E, Persson A, Chang D. Accumulation of surfactant protein $D$ in human pulmonary alveolar proteinosis. Am J Pathol 1993; 142:241-8.

48. Du Bois RM, McAllister WA, Branthwaite MA. Alveolar proteinosis: diagnosis and treatment over a 10 -year period. Thorax 1983; 38:360-3.

49. Green D, Griner GJ. Twenty-five year follow-up of a patient treated with lung lavage for pulmonary alveolar proteinosis. N Engl J Med 1987; 317:839-40.

50. Bewig B, Wang X-D, Kirsten D, Dalhoff K, Schäfer H. GMCSF and GM-CSF $\beta$ c receptor in adult patients with pulmonary alveolar proteinosis. Eur Respir J 2000; 15:350-7.

51. Seymour JF, Dunn AR, Vincent JM, Presneill JJ, Pain MC. Efficacy of granulocyte-macrophage colony-stimulating factor in acquired alveolar proteinosis. N Eng J Med 1996; 335:1924-5.

52. Kitamura T, Tanaka N, Watanabe J, Uchida K, Kanegasaki $\mathrm{S}$, Yamada $\mathrm{Y}$, et al. Idiopathic pulmonary alveolar proteinosis as an autoimmune disease with neutralizing antibody against granulocyte/macrophage colony-stimulating factor. J Exp Med 1999; 190:875-80.

53. Kitamura T, Uchida K, Tanaka N, Tsuchiya T, Watanabe J, Yamada $Y$, et al. Serological diagnosis of idiopathic pulmonary alveolar proteinosis. Am J Respir Crit Care Med 2000; 162:658-62.

54. Dirksen U, Nishinakamura R, Groneck P, Hattenhorst U, Nogee L, Murray R. Human pulmonary alveolar proteinosis associated with a defect in GM-CSF/L-3/IL-5 receptor common $\beta$ chain expression. J Clin Invest 1997; 100:2211-7.

55. Moulton SL, Krous HF, Merritt TA, Odell RM, Gangitano E, Cornish JD. Congenital pulmonary alveolar proteinosis: failure of treatment with extracorporeal life support. J Pediatr 1992; 120:297-302.
56. Nogee LM, deMello DE, Dehner LP, Colten HR. Deficiency of pulmonary surfactant protein $\mathrm{B}$ in congenital alveolar proteinosis. N Engl J Med 1993; 328:406-10.

57. Cole FS, Hamvas A, Rubinstein P, King E, Trusgnich M, Nogee LM, et al. Population-based estimates of surfactant protein B deficiency. Pediatrics 2000; 105:538-41.

58. Vorbroker DK, Profitt SA, Nogee LM, Whitsett JA. Aberrant processing of surfactant protein $\mathrm{C}$ in hereditary SP-B deficiency. Am J Physiol 1995; 268:L647-56.

59. Tredano M, van Elburg RM, Kaspers AG, Zimmermann LJ, Houdayer C, Aymard P, et al. Compound SFTPB 1549C $\rightarrow$ GAA (121ins2) and 457delC heterozygosity in severe congenital lung disease and surfactant protein B (SP-B) deficiency. Hum Mutat 1999; 14:502-9.

60. deMello DE, Nogee LM, Heyman S, Krous HF, Hussain M, Merritt TA, et al. Molecular and phenotypic variability in the congenital alveolar proteinosis syndrome associated with inherited surfactant protein B deficiency. J Pediatr 1994; 125:43-50.

61. deMello DE, Heyman S, Phelps DS, Hamvas A, Nogee L, Cole $\mathrm{S}$, et al. Ultrastructure of lung in surfactant protein B deficiency. Am J Respir Cell Mol Biol 1994; 11:230-9.

62. Janssen DJ, Carnielli VP, Bunt JEH, Luijendijk IH, Wattimena $D$, Tibboel $D$, et al. Surfactant phosphatidylcholine (PC) metabolism in term infants with congenital surfactant protein-B (SP-B) deficiency studied with stable isotopes. Eur Resp J 1999; 14:249s(1696).

63. Nogee LM, Garnier G, Dietz HC, Singer L, Murphy AM, deMello $D E$, et al. A mutation in the surfactant protein $B$ gene responsible for fatal neonatal respiratory disease in multiple kindreds. J Clin Invest 1994; 93:1860-3.

64. de la Fuente AA, Voorhout WF, deMello DE. Congenital alveolar proteinosis in The Netherlands: a report of five cases with immunohistochemical and genetic studies on surfactant apoproteins. Pediatr Pathol Lab Med 1997; 17:221-31.

65. Stuhrmann M, Bohnhorst B, Peters U, Bohle RM, Poets CF, Schmidtke J. Prenatal diagnosis of congenital alveolar proteinosis (surfactant protein B deficiency). Prenat Diagn 1998; 18:953-5.

66. Nogee LM, Wert SE, Proffit SA, Hull WM, Whitsett JA. AIlelic heterogeneity in hereditary surfactant protein B (SPB) deficiency. Am J Respir Crit Care Med 2000; 161:973-81.

67. Tredano M, Cneude F, Denamur E, Truffert P, Capron F, Manouvrier $S$, et al. Déficit constitutionnel en protéine $B$ du surfactant pulmonaire: présentation clinique, diagnostic histologique et moléculaire. Arch Pédiatr, 2000; 7:641-4.

68. Somaschini M, Wert S, Mangili G, Colombo A, Nogee L. Hereditary surfactant protein $B$ deficiency resulting from a novel mutation. Intensive Care Med 2000; 26:97-100.

69. Lin Z, deMello DE, Wallot M, Floros J. An SP-B gene mutation responsible for SP-B deficiency in fatal congenital alveolar proteinosis: evidence for a mutation hotspot in exon 4. Mol Genet Metab 1998; 64:25-35.

70. Williams GD, Christodoulou J, Stack J, Symons P, Wert SE, Murrell MJ, et al. Surfactant protein B deficiency: clinical, histological and molecular evaluation. J Paediatr Child Health $1999 ; 35: 214-20$.

71. Klein JM, Thompson MW, Snyder JM, George TN, Whitsett JA, Bell EF, et al. Transient surfactant protein B deficiency in a term infant with severe respiratory failure. $\mathrm{J} \mathrm{Pe}$ diatr 1998; 132:244-8.

72. Dunbar $A E$, Wert $S E$, Ikegami M, Whitsett JA, Hamvas $A$, White FV, et al. Prolonged survival in hereditary surfactant protein B (SP-B) deficiency associated with a novel splicing mutation. Pediatr Res 2000; 48:275-82.

73. Ballard PL, Nogee LM, Beers MF, Ballard RA, Planer BC, 
Polk L, et al. Partial deficiency of surfactant protein B in an infant with chronic lung disease. Pediatrics 1995; 96:1046-52.

74. Antonorakis SE, the Nomenclature Working Group. Recommendations for a nomenclature system for human gene mutations. Hum Mutat 1998; 11:1-3.

75. Hamvas A, Nogee LM, Mallory GB Jr, Spray TL, Huddleston $C B$, August $A$, et al. Lung transplantation for treatment of infants with surfactant protein B deficiency. J Pediatr 1997; 130:231-9.

76. Yusen RD, Cohen AH, Hamvas A. Normal lung function in subjects heterozygous for surfactant protein-B deficiency. Am J Respir Crit Care Med 1999; 159:411-4.

77. Clark JC, Weaver TE, Iwamoto HS, Ikegami M, Jobe AH, Hull WM, et al. Decreased lung compliance and air trapping in heterozygous SP-B-deficient mice. Am J Respir Cell Mol Biol 1997; 16:46-52.

78. Beers MF, Hamvas A, Moxley MA, Gonzales LW, Guttentag $\mathrm{SH}$, Solarin $\mathrm{KO}$, et al. Pulmonary surfactant metabolism in infants lacking surfactant protein B. Am J Respir Cell Mol Biol 2000; 22:380-91.

79. Beck DC, Ikegami M, Na C-L, Zaltash S, Johansson J, Whitsett JA, et al. The role of homodimers in surfactant protein B function in vivo. J Biol Chem 2000; 275:3365-70.

80. Beck DC, Na C-L, Whitsett JA, Weaver TE. Ablation of a critical surfactant protein $B$ intramolecular disulfide bond in transgenic mice. J Biol Chem 2000; 275:3371-6.

81. Cutz E, Wert SE, Nogee LM, Moore AM. Deficiency of lamellar bodies in alveolar type II cells associated with fatal respiratory disease in a full-term infant. Am J Respir Crit Care Med 2000; 161:608-14.

82. Kala P, Koptides M, Diangelo S, Hoover RR, Lin Z, Veletza V, et al. Characterization of markers flanking the human SP-B locus. Dis Markers 1997; 13:153-67.
83. Tredano M, Lacaze T, Camboni G, Houdayer C, Delaisi B, Feillet $F$, et al. Molecular analysis of the $S P-B$ gene in primitive pulmonary alveolar proteinosis. Am J Hum Genet 1998; 63:A389(2260).

84. Bünger H, Kaufner L, Pison U. Quantitative analysis of hydrophobic pulmonary surfactant proteins by high-performance liquid chromatography with light-scattering detection. J ChromatogrA 2000; 870:363-9.

85. Dirksen U, Hattenhorst U, Schneider P, Schroten H, Göbel $U$, Böcking A, et al. Defective expression of granulocytemacrophage colony-stimulating factor/interleukin-3/interleukin- 5 receptor common $\beta$ chain in children with acute myeloid leukemia associated with respiratory failure. Blood 1998; 92:1097-103.

86. Reed JA, Whitsett JA. Granulocyte-macrophage colonystimulating factor and pulmonary surfactant homeostasis. Proc Assoc Am Physicians 1998; 110:321-32.

87. Haataja R, Rämet M, Marttila R, Hallman M. Surfactant proteins $A$ and $B$ as interactive genetic determinants of neonatal respiratory distress syndrome. Hum Mol Genet 2000; 9:2751-60.

Received 13 October 2000, revised 30 January 2001, accepted 1 February 2001

Corresponding authors: Drs. M. Tredano and M. Bahuau, Service de Biochimie et Biologie Moléculaire, Hôpital d'Enfants Armand-Trousseau, 26 Avenue du Docteur Arnold-Netter, 75571 Paris Cedex 12, France

Tel: +33 (0)1 447363 56, Fax: +33 (0)1 44736687

E-mail: assistants.bm@trs.ap-hop-paris.fr 